\title{
Weber Revisited: The Protestant Ethic and the Spirit of Nationalism
}

\author{
Felix Kersting, Iris Wohnsiedler, and Nikolaus Wolf
}

We revisit Max Weber's hypothesis on the role of Protestantism for economic development. We show that nationalism is crucial to both, the interpretation of Weber's Protestant Ethic and empirical tests thereof. For late nineteenth-century century Prussia we reject Weber's suggestion that Protestantism mattered due to an "ascetic compulsion to save." Moreover, we find that income levels, savings, and literacy rates differed between Germans and Poles, not between Protestants and Catholics, using pooled OLS and IV regressions. We suggest that this result is due to anti-Polish discrimination.

E conomists increasingly acknowledge the role of "culture" for economic development, related to a new, broader approach in economics to human behavior and decision making. One of the most influential ideas today stems from Max Weber's work more than one century ago. Weber $(1904,1905)$ famously hypothesized that a specific Protestant work ethic fostered modern economic development due to a "compulsion to save." He motivated this with some statistical evidence on differences between Protestants and Catholics in Baden around 1900 and used anecdotal evidence to suggest a much more general relationship.

In this paper, we revisit Weber's hypothesis and the evidence on it for nineteenth-century Germany. We argue that the "common interpretation" (Delacroix and Nielsen 2001) of Weber has often missed his own argument on saving behavior as the key mechanism. Moreover, it missed Weber's nationalist and anti-Polish bias. Weber wrote in a context where

The Journal of Economic History, Vol. 80, No. 3 (September 2020). (C) The Economic History Association. All rights reserved. doi: 10.1017/S0022050720000364. This is an Open Access article, distributed under the terms of the Creative Commons Attribution licence (http://creativecommons.org/licenses/by/4.0/), which permits unrestricted re-use, distribution, and reproduction in any medium, provided the original work is properly cited.

Felix Kersting is Ph.D. student, Department of Economics, Humboldt University of Berlin, Spandauer Straße 110178 Berlin Germany. E-mail: f.kersting@hu-berlin.de. Iris Wohnsiedler is Research Assistant, Department of Economics, Humboldt University of Berlin, Spandauer Straße 110178 Berlin Germany. E-mail: wohnsiei@hu-berlin.de. Nikolaus Wolf is Professor, Department of Economics, Humboldt University of Berlin, Spandauer Straße 110178 Berlin Germany. E-mail: nikolaus.wolf@wiwi.hu-berlin.de.

We would like to thank Dan Bogart (the editor), four anonymous referees, Thilo Albers, Robert Allen, Till Breyer, Stephen Broadberry, Gabriel Felbermayr, Beata Javorcik, Sibylle LehmannHasemeyer, Martin Lutz, Alexander Nuetzenadel, Albrecht O. Ritschl, Kevin O'Rourke, Max-Stephan Schulze, Joachim Winter, and seminar participants at Oxford, Rome, Leipzig, York, CRC TRR 190 Workshop in Berlin 2018, and CEPR Conference on "The Economics of Religion" in Venice 2019 for very helpful comments. Furthermore, we would like to thank Sibylle Lehmann-Hasemeyer and Fabian Wahl for providing data on the savings-banks. Financial support by Deutsche Forschungsgemeinschaft through CRC TRR 190 is gratefully acknowledged. 
religious differences (between Catholics and Protestants) overlapped with ethno-national differences (between Poles and Germans), and he was well aware of this. Max Weber was a passionate German nationalist, and his writing, including the "Protestant Ethic" (PE), should also be understood as a contribution to political education of the German public (Barbalet 2008). In fact, the PE should be seen as much as an "intervention into German political concerns than an account of the emergence of capitalism" (Scott 2009, p. 903). We show empirically that we need to modify the so-called "common interpretation" twofold: with a focus on savings as a mechanism by which religion might have affected economic outcomes and by controlling for differences between ethnic groups as a possibly crucial confounding factor.

Prussia in the nineteenth century provides us with rich variation for a new test of Weber's PE. Starting with basic descriptive evidence we show that income levels, savings and literacy rates across Prussia after 1870 are more strongly correlated with differences between ethnic groups than with those between religious denominations. Simple ordinary least squares (OLS) regressions suggest that ethnicity is likely to be a crucial factor in explaining the large variation in outcome variables across the German Empire. To provide causal evidence on the role of culture for development, we follow Acemoglu (2009) and distinguish between proximate and fundamental causes of economic growth. We focus on savings and literacy rates as possible proximate causes of growth, and on religion capturing aspects of culture as a potential fundamental cause of growth. We then use an instrumental variable (IV) approach to test for causality: income levels, savings, and literacy rates did not differ between Protestants and Catholics, but differed between Germans and Poles. Let us explain in more detail, how we come to this conclusion.

In a first step of our empirical analysis we revisit the evidence on the underlying mechanism, motivated by reading again Weber's original text. Weber suggested that Protestantism might have led to an "accumulation of capital through ascetic compulsion to save" (Weber 1905, p. 191). This idea has recently been formalized by Alaoui and Sandroni (2018). To test for it more directly, we use a recent data-set from Lehmann-Hasemeyer and Wahl (2017) on savings per capita and the number of savings banks for all Prussian counties, available for the years 1875, 1882, 1888, 1898, and 1904. To test for a causal effect of Protestantism on savings, we use an IV based on religious denominations as of 1624, following Spenkuch (2017). The IV is constructed by regressing Protestant in 1624 on predictors of rulers' choices, as identified by the previous literature, notably Cantoni (2012) and Rubin (2014). The residuals are used as instrument 
for the share of Protestants after 1870 . We show that the instrument is strong and robust to violations of the exclusion restriction. We find no significant effect of Protestantism on savings, neither in OLS nor IV. This finding is also robust to variations in the sample, alternative specifications, the inclusion of income per capita as a regressor, and a distinction between Lutherans and Reformed Protestants. In contrast, we find that ethnic differences as measured by the share of German speakers are strongly correlated with savings per capita.

Next, we test for the idea that Protestantism mattered not due to a change in attitudes towards work and consumption, but because it fostered literacy as argued by Becker and Woessmann (2009). We first provide new descriptive evidence on the difference in literacy rates among Protestants and Catholics at the county level from a historical cross table, which has been largely neglected in the literature. We show that at the county level literacy rates among Catholics are nearly identical to literacy rates among Protestants. The only exception to this are counties with a substantial share of Polish population. Second, we test for a causal effect of religion on literacy, using again the IV approach by Spenkuch (2017). We find that Protestantism had no significant effect. The coefficient on ethnic differences is much larger and statistically and economically significant.

This set of results leaves us with a new puzzle. Apparently, religious differences help very little to understand the large variation in terms of economic development across nineteenth-century Imperial Germany, respectively Prussia. A naive interpretation of Weber's PE can, therefore, be clearly refuted in our context. Also, the more sophisticated interpretation of a role of Protestantism via literacy rates finds no support in the data. We note that this does not rule out that ascetic Protestantism had causal effects centuries before, which indirectly may have affected Catholics and indeed secularization. An alternative interpretation could place Weber's argument in the context of technological change or test for altogether different mechanisms on how the Protestant Reformation might have caused economic development (Cantoni, Dittmar, and Yuchtman 2018). But our findings suggest that differences in religion between Catholics and Protestants (encompassing Lutherans) had little persistence, hence they cannot be considered to be "fundamentals" without further qualification. Instead, our evidence highlights the enormous differences between ethnic groups (Germans and Poles) that existed around 1900 in Prussia, dwarfing any differences between Protestants and Catholics. This new result is in line with most of the historical literature on the German Empire, which stresses rising national tensions and abating religious conflict after the end of the Kulturkampf (Wehler 2006). 
In the last part of our paper, we discuss this relationship between ethnicity and economic outcomes and suggest some lines for further research. This issue is important, not only due to very high correlation between differences in economic outcomes, ethnic groups, and religion, but also because Weber himself considered ethnicity as crucial. In his earlier writing he attributed differences in economic outcomes between Germans and Poles to racial differences (Weber 1895), and actively supported a stronger Germanization of the eastern parts of Germany. Thus Weber's nationalist position not only puts a different light on the PE (as discussed in recent research in sociology), but also offers a contemporary point of reference for explaining these differences, namely German discrimination. We document that after 1871 the German majority increasingly discriminated against the Polish minority in terms of language and education policy, and also when it came to access to public offices and policies of land redistribution. Poles might have reacted to this with attempts to create substitutes, such as education outside of state schools or the emergence of Polish land and credit cooperatives. More research along these lines is needed to understand, to what extent Germanization can account for the observed large differences in incomes, savings, and literacy rates, which we documented above.

Our paper contributes to several strands of research. First, we add to the growing literature on the role of culture, and specifically religion for economic development. One part of the literature has focused on theoretical arguments, how culture can affect preferences, behavior, and outcomes, including Bénabou and Tirole (2004, 2006, 2011), Tabellini (2008), Doepke and Zilibotti (2008), and Alaoui and Sandroni (2018). To some extent, this literature can be seen as an attempt to rationalize the behavioral consequences of cultural attitudes, such as Weber's proposition that ascetic Protestantism leads to increased savings and wealth accumulation. Another part of that literature seeks to test for the role of culture for economic development empirically, see Iannaccone (1998), Barro and McCleary (2003), Becker and Woessmann (2009), Cantoni (2015), Spenkuch (2017), and Becker, Pfaff, and Rubin (2016) for a review. Our first contribution is a focus on savings behavior as a mechanism that links Protestantism and economic development. This mechanism is of importance as it is at the core of Weber's PE and also central to much of the recent theoretical literature, including Alaoui and Sandroni (2018). We can clearly reject this hypothesis for late nineteenth-century Prussia. Another contribution is that we reconsider a prominent alternative hypothesis, suggested by Becker and Woessmann (2009): that Protestantism mattered for development via literacy rates. 
Again, we can reject this hypothesis in our context. We provide new direct evidence at the county level that literacy rates between Protestants and Catholics in 1871 did not differ. Instead, we show that literacy rates differed a lot between ethnic groups, which the previous literature did not consider.

Next, we show that nationalism and ethnic conflict is key for both, an understanding of Weber's PE and an understanding of differences in terms of economic development. The former is well known in the sociological and historical literature on Weber and the PE (e.g., Mommsen 2004; Zimmerman 2006; Barbalet 2008), but has been largely ignored in the economic literature on the topic. Our contribution here is to remind economists about the context in which Weber was writing (Margo 2017), and to show empirically that ethnic differences are indeed a crucial confounding factor. While our data is for Germany in the late nineteenth century, we think that religious and ethnic differences may be more systematically related. Our findings suggest that the previous literature may have overestimated the role of religion by failing to take ethnic differences into account.

Finally, we contribute to the literature on the long-run economic development of Germany (Broadberry and Burhop 2007; Grant 2005; Wolf 2009; Hornung 2015; Bartels 2019). We document that the German Empire was characterized by fragmentation between religious groups, between different ethnic groups, territories with different historical legacies, a growing rural-urban divide, and growing economic inequality. The economic development of Germany before WWI was, to some extent, shaped by these lines of fragmentation (e.g., Wolf 2009). Recently, Cinnirella and Schueler (2016) have shown that fragmentation along ethnolinguistic lines mattered for education policies. Our empirical results suggest that they mattered more generally for differences in economic development.

The rest of the paper is organized as follows. In the second section we briefly review Weber's essay on the PE and the "common interpretation" of it that has served as a workhorse for much of the recent work on the subject. The third section provides historical background on economic development across late nineteenth-century Germany. In the fourth section we state our main hypotheses and discuss our empirical strategy to test for causality. The fifth section contains our main results on income, savings, and literacy rates as well as several robustness checks. In the sixth section we discuss how discriminatory policies might account for the observed role of ethnic differences, before we conclude in the seventh section. 


\section{WEBER'S PROTESTANT ETHIC AND THE "COMMON INTERPRETATION"}

Weber's work "The Protestant Ethic and the Spirit of Capitalism" is a founding text for sociology and continues to be widely discussed, also in neighboring disciplines such as history and economics. The text was first published in two parts in 1904 and 1905 and immediately received much attention, praise, and critique. In 1920 Weber published a revised version that incorporated some of the earlier discussion and is the basis for all following debates as well as translations (Lehmann and Roth 1995). The interpretation of the PE has changed over time, which is to some extent due to the complexity but also the ambiguity of Weber's arguments (MacKinnon 1995). We cannot even superficially review the entire discussion, but focus instead on some aspects, which have been taken up in the more recent empirical (and mostly economic) literature.

A convenient starting point is the "common interpretation" of Weber's hypothesis as formulated by Delacroix and Nielsen (2001, p. 511) and Nolan and Lenski (2014). which is central for the recent empirical literature on the subject. Given the vast literature on the PE and its appropriate exegesis, these authors condensed a simplified, yet testable summary as follows: (1) The Protestant Reformation fostered new attitudes, (2) the new attitudes (the PE) affected behaviors, and (3) the new attitudes and behaviors favored economic development and contributed to industrialization around the world. It is this interpretation of Weber's PE, which has been recently tested and discussed in the economics literature.

The "common interpretation" remains unspecific about the possible mechanism that might lead from a change in attitude to a change in behavior and finally economic development. This is due to the fact that Weber himself was eager to provide many caveats. At the beginning of his essay, he pointed out that there might be an issue of reverse causation, namely that it was the richer parts of the Empire, notably rich cities that first adopted Protestant ideas in the sixteenth century. He also suggested that a higher income of Protestants around the time of his writing could result from various historical factors and in turn contribute to observed differences in economic behavior. Towards the end of his essay, he suggested that a thorough analysis would have to examine how a Protestant work ethic may have affected the organization of societies and their political institutions as well as the formation of modern science and technology, among other things. But at the heart of his essay stand clear statements about one particular underlying mechanism. In Weber's view, the formation of a new attitude (ascetic Protestantism) leads to a change 
in behavior, namely a limitation of consumption and increased economic activity, so that "the inevitable practical result is obvious: accumulation of capital through ascetic compulsion to save" (Weber 1905, p. 191). ${ }^{1}$

Influential empirical contributions include Delacroix and Nielsen (2001), Barro and McCleary (2003), Becker and Woessmann (2009), Cantoni (2015), and Spenkuch (2017). Delacroix and Nielsen (2001) explore the correlation between cross-country evidence on measures of the share of Catholics and Protestants on various indicators for economic development, including measures of wealth, savings bank deposits per capita, extent of the railroad network, and others. Overall, they find only limited empirical support for the "common interpretation". Barro and McCleary (2003) use a global cross-country data set to test for a relationship between religious beliefs, church attendance, and economic outcomes. They employ paneldata estimation and find that religious beliefs matter, notably belief in Hell, after controlling for church attendance and considering reverse causation. Becker and Woessmann (2009) use data on Prussian counties from the late nineteenth century, the time when Weber was writing, and find a causal link from Protestantism to economic development. However, they argue that this can be fully explained by higher literacy rates among Protestants rather than any effect of religious attitudes. Cantoni (2015) uses panel data on city growth as an indicator for economic development across the Holy Roman Empire for the centuries 1300 to 1900 and finds no effects of differences in confessions. Spenkuch (2017) uses microdata from the Socio-Economic Panel (SOEP) on Germany today to test for differences between Protestants and Catholics in terms of their attitudes, behaviors, and outcomes. He finds some evidence suggesting that Protestants work longer hours due to different work ethic as captured in specific survey questions.

Why does the "common interpretation" and most of the empirical work on it neglect Weber's own and very sharp distinction between Lutheranism and ascetic Protestantism such as Calvinism? Weber stressed the role of "calling," which is the religious and irrational underpinning of the PE. Weber argued that for Luther this concept of calling remained traditionalistic while for Calvinists it implied a restless striving for worldly success. $^{2}$ The common failure to distinguish between Lutheranism and

\footnotetext{
${ }^{1}$ In the translation by Talcott Parsons see Weber (1930, p. 172). In line with this reasoning, Dohmen et al. (2018) find a strong reduced form relation between patience and economic development using a large global data set on time preferences of individuals.

${ }^{2}$ As shown in Graf (1995, p. 41ff.), Weber argued here against the contemporary mainstream view defined by the theologian Albrecht Ritschl and his students, who regarded Lutheranism as the cornerstone of the new German nation state. However, while both considered Catholics as traditionalists and culturally inferior, for Weber Lutheranism represented a "deficient form of Protestant religiosity, closer to the level of traditionalist Catholic conduct than to the ethical activity of the Calvinists" (Graf 1995, p. 45).
} 
other Protestant denominations in the empirical literature is in part due to Weber's own use of evidence in the PE: on the very first page of the PE, Weber motivates his work with statistical data on differences in school attendance between Catholics and Protestants in Baden, drawn from his student Martin Offenbacher (1901). Apart from some statistical errors that actually exaggerate these differences (Becker 1997), the data does not allow us to distinguish between Lutherans and other Protestants. Hence, Weber himself placed his argument in the context of apparently striking differences between Catholics and Protestants - only to elaborate further on the dynamic nature of ascetic Protestantism and implicitly stressing the backwardness of Catholicism.

The "common interpretation" rests on the assumption that Weber's text should be seen as a study in the origins of modern capitalism and economic development. But much of the recent literature on Weber stresses the contemporary context in which he wrote, notably the political dimension of his writings and the place of the PE in relation to his earlier work. Wolfgang Mommsen (2004, p. 38), the editor of the collected writings of Max Weber, stated that his inaugural lecture (IL), given at the University of Freiburg in 1895, was the most important document of the political Max Weber until WWI, which is relevant in this context. Under the title "The National State and Economic Policy" (original "Der Nationalstaat und die Volkswirtschaftspolitik"), Weber states that he wants to clarify "the role of physical and psychological racial differences between nationalities in the economic struggle for existence" (Weber 1895, p. 545). His example are the differences in the Prussian province of West Prussia between Poles and Germans. Quoting statistical evidence, he suggests that while Polish peasants live on less fertile ground, they are less prone to out-migrate than German peasants in response to the recent agricultural crisis, resulting in "economic displacement" of Germans by Poles. His hypothesis is that this is rooted in different attitudes between the two nationalities, specifically the "lower requirements about the standard of living [...], which the Slavic race has by its nature or acquired over its past" (Weber 1895, p. 551). Hence, already ten years before the $\mathrm{PE}$, in his IL in 1895 , Weber argued that different attitudes can lead to different behavior (in this case migration), and outcomes (the displacement of Germans by Poles). Crucially, he demands that economic policy ought to stop this, because "our state is a national state" (Weber 1895, p. 558). According to Ernst Tröltsch, "die nationale Kraft und Größe" ("the national power and greatness," own translation) was the only "Wertgott" whom Weber unconditionally worshiped (Troeltsch 1922, p. 161). Based on the example of the national conflict between Poles and 
Germans in the East, for Weber the (Lutheran) Prussian Junkers have failed to provide political leadership. He concluded that the German bourgeoisie is in urgent need of political education (Weber 1895, pp. 570-73). ${ }^{3}$ Barbalet (2001) drew a line from the arguments Weber made in his IL to the PE. He suggested that in the PE of 1904/1905 Weber took up this challenge first formulated in his Freiburg lecture and provided a solution to the problem of political education: to face the threat to the German nation, in particular, the threat of Polonization, Weber argued that the Lutheran German elites needed a new calling, and ascetic Protestantism could provide it.

This reading of Weber's PE is more than a historical footnote, because it affects our priors. It is unclear whether we should expect to find any substantial differences between Protestants and Catholics across nineteenth-century Germany in terms of indicators for economic development. In the next section, we briefly provide some relevant historical background on this.

\section{ECONOMIC DEVELOPMENT AND POLITICAL TENSIONS IN IMPERIAL GERMANY}

The German Empire at the time of the first publication of Weber's PE in 1904 and 1905 was characterized by a dynamically growing economy together with increasing social and political tensions. Between 1850 and 1910 Germany developed from a backward economy into Europe's industrial core.

The war against France in 1870/1871 had led to the formation of a new political entity - the German Empire-which was highly heterogeneous, given its rather small size. The Prussian state had a leading position, representing about 60 percent of the entire population. But Prussia itself was heterogeneous, split between dynamic cities such as Berlin and backward agrarian regions, old Prussian territories such as Brandenburg, and new ones recently conquered after the Napoleonic Wars such as the Rhineland (1815), Hannover (1866), or Schleswig-Holstein (1866). And most importantly, Prussia experienced conflicts between Catholics and Protestants, and between Germans, Poles, and other national minorities.

\footnotetext{
${ }^{3}$ Weber maintained his anti-Polish nationalism until the end of his life. In 1899 he resigned from the nationalist Pan-German league because he believed the organization had given in to the interests of agrarian capitalists allowing the influx of cheap Polish migrants instead of fighting the Polish threat (Zimmerman 2006, p. 64). While Weber turned into a critic of German colonialism later in his life, still in 1918 he agitated during a lecture against Polish officials who would dare to enter the contested city of Danzig, and proposed they should be shot (Zimmerman 2006, p. 64).
} 
Hence, after the formation of the Empire in early 1871, its character as a nation state remained contested and Prussia as the largest and most influential state was the central arena for these public debates. The first line of conflict opened between the Prussian state on one side and the Catholic church and catholic organizations on the other, the Kulturkampf. While the conflict between the Catholic Church and state authorities was a European phenomenon at the time, the dispute was especially intense in the German Empire. In Alsace-Lorraine and the eastern Provinces of Prussia this conflict overlapped with resistance of national minorities against German nationalism, because these minorities were overwhelmingly Catholic. From the Polish perspective this Kulturkampf was considered first and foremost an attack on Polish identity (Trzeciakowski 1970). Here the conflict between state and church was fierce (e.g., the Catholic Archbishop of Gniezno and Poznan Ledochowski was imprisoned 18741876) and it coincided with the first steps of repression against the Polish language in primary and secondary schools after 1871 (Knabe 2000).

The situation changed with Bismarck's political turn in 1878/1879, which ended the Kulturkampf, but opened new lines of conflict against Socialists and national minorities accompanied by rising antisemitism and protectionism. The decades between 1880 and WWI were characterized by swelling German nationalist sentiments, reflected, for example, in the growth of nationalist Kriegervereine (veteran organizations). Their membership increased from 71,900 (below 1 percent of the male population) in 1873 to 2.8 million in 1913 (above 8 percent of the male population), more than all trade unions in the Empire (Kersting 2017). Especially the Poles in the East of Prussia were considered as a threat to the German state and faced harsh oppression. The Geschäftssprachengesetz of 1876 and the Gerichtsverfassungsgesetz of 1877 prohibited the use of Polish in administration and the judiciary (Wehler 2006). Under Prussia's new minister for education, Gustav von Gossler, from 1881 onwards there was a wave of new anti-Polish measures in an attempt to stifle the use of Polish language in schools and to reduce the number of Polish teachers. After years of discussion, in 1901 the Prussian state attempted to eliminate the Polish language also from religious education, which immediately triggered a first local school strike in the city of Wrzesnia in 1901. It was followed by a much larger strike in 1906. The Prussian state responded with disciplinary measures and the strike was finally broken, but the tensions about language policy and indeed national identity of Poles and Germans did not abate.

Hence, late nineteenth-century Germany was indeed characterized by fundamental conflicts between religious denominations and nationalities, 
which intensified after the formation of the German Empire in 1871 and in waves thereafter. To what extent were these conflicts reflected in economic outcomes at the time? Wolf (2009) has shown that language differences mattered much more than religious differences as a barrier to internal trade flows within the Empire between 1885 and 1913. In the next sections we will analyze whether language and religious denominations were systematically related to different levels of economic development, whether this can be interpreted as causal, and what might be the mechanisms underneath.

\section{HYPOTHESIS, DATA, AND EMPIRICAL STRATEGY}

In our empirical analysis, we focus on differences in terms of income levels, literacy rates and savings as indicators for economic development across Prussian counties and over time. Specifically, we aim to test the following three hypotheses.

H1: Protestantism had a causal effect on saving behavior.

H2: Protestantism had a causal effect on literacy rates.

H3: Ethnic differences are an omitted variable in the "common interpretation."

We distinguish between proximate and fundamental causes of economic growth (Acemoglu 2009). Proximate causes include differences in technology, physical capital (as reflected in savings), and human capital (as reflected in literacy rates), fundamental causes include geographical factors (e.g., coal resources), institutions (e.g., property rights), and culture (e.g., a specific work ethic).

To test our first hypothesis, we investigate the causal effect of Protestantism on savings as a specific proximate cause for development that, in turn, may have affected long-run growth and income levels. To do so, we use regional data on Sparkassen (savings banks) provided by Lehmann-Hasemeyer and Wahl (2017). The first savings bank was founded in 1778 in Hamburg and intended to serve the benefit of "poor, industrious persons of both sexes, working as servants, day laborers, manual workers, seafarers etc.," in order to give them the opportunity to save money (von Knebel Doeberitz 1907, p. 2). Savings banks combined the functions of deposit banks and credit institutions, whereby they were meant to fulfill their purpose as an institution for the prevention of poverty. In contrast to social insurance provided by the state, saving 
is left to the free choice of the individual. Thus, data on the deposits in savings banks allow us to observe the savings behavior of medium- to lower-income groups, who were encouraged to save so they could pay for unforeseen expenses and re-invest the money in their agricultural or craft business, thereby contributing to a better standard of living in the long term (Trende 1957, p. 129). ${ }^{4}$

While capital accumulation in agricultural and commercial credit cooperatives was needed to ensure the supply of credits to the members of the cooperatives, fostering savings was an end in itself for the savings banks (Trende 1957), corresponding to Weber's emphasis on the importance of savings for economic development. Due to their specific purpose and the focus on broader parts of the population as their customers, we argue that savings banks are an appropriate institution to study regional differences in savings within Prussia. Additionally, the so-called Regionalprinzip (regional principle), according to which it was not possible to open an account if one did not live in that region, ensures that the savings deposits reflect the propensity to save of a county (Lehmann-Hasemeyer and Wahl 2017).

Figures 1 and 2 show the geographic distribution on the savings per capita in 1880 and 1905, which sharply increase during this time. In most regions, except for the eastern provinces, savings per capita are above 100 Mark in 1905. Moreover, almost every county had at least one savings bank. Can differences in religious denomination possibly account for these differences in savings? Figure 3 shows the geographic distribution of Protestantism in Prussia as of 1900, and suggests that there might indeed be some relation.

The data on savings is available for the years $1875,1882,1888,1898$, and 1904. We link this data with the closest available census to calculate savings per capita. We estimate the following specification:

$$
\operatorname{Sav}_{i t}=\alpha_{1}+\beta_{1} \operatorname{Prot}_{i t}+X_{i t}^{\prime} \gamma_{1}+\varepsilon_{1 i t}
$$

where $S a v_{i t}$ indicates savings per capita in county $i$ and year $t$, Prot $_{i t}$ the share of Protestants, $X_{i t}$ time-varying control variables including urban population, the number of savings banks, household size, and share of

\footnotetext{
${ }^{4}$ We note that our data might imply some bias if higher incomes from entrepreneurial and industrial activity would systematically differ between Protestants and Catholics. While this would require further research, the available evidence suggests that there was no such bias in the Prussian data before 1914. First, the share of income millionaires in the population was not correlated with Protestantism in 1912 (Martin 1912). Second, using the Prussian tax statistics we find that the share of capital income in total income of a district was not correlated with Protestantism between 1893 and 1910 (Bartels, Kersting, and Wolf 2019).
} 


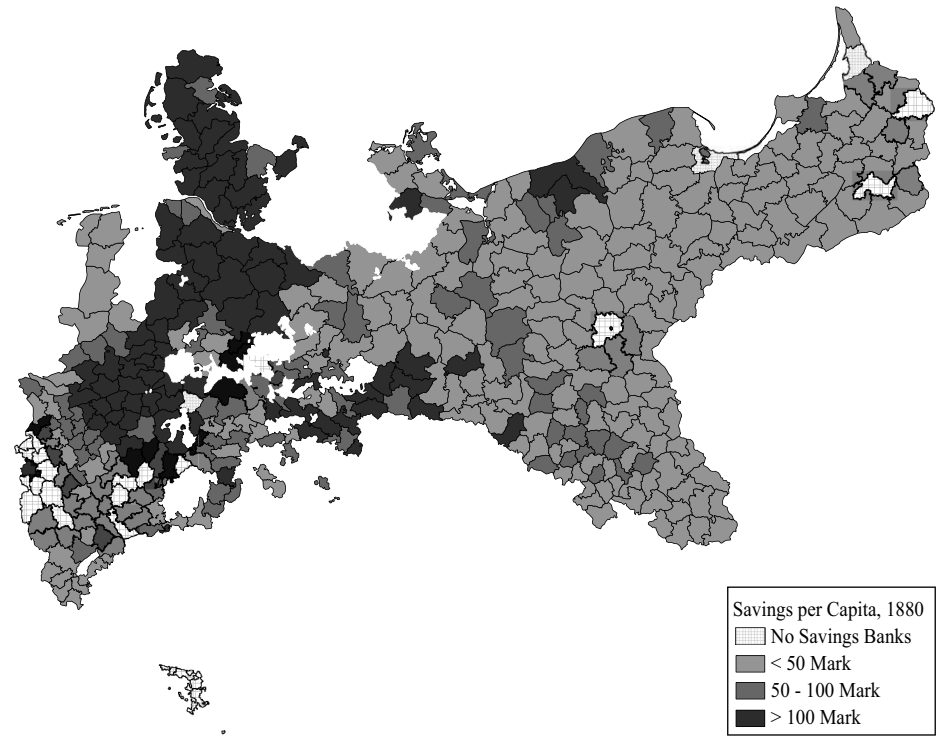

FIGURE 1

SAVINGS PER CAPITA, 1880

Notes: Darker colors correspond to higher savings per capita. White colored counties do not have a savings bank in 1880 .

Source: See Table B.1 in the Online Appendix.

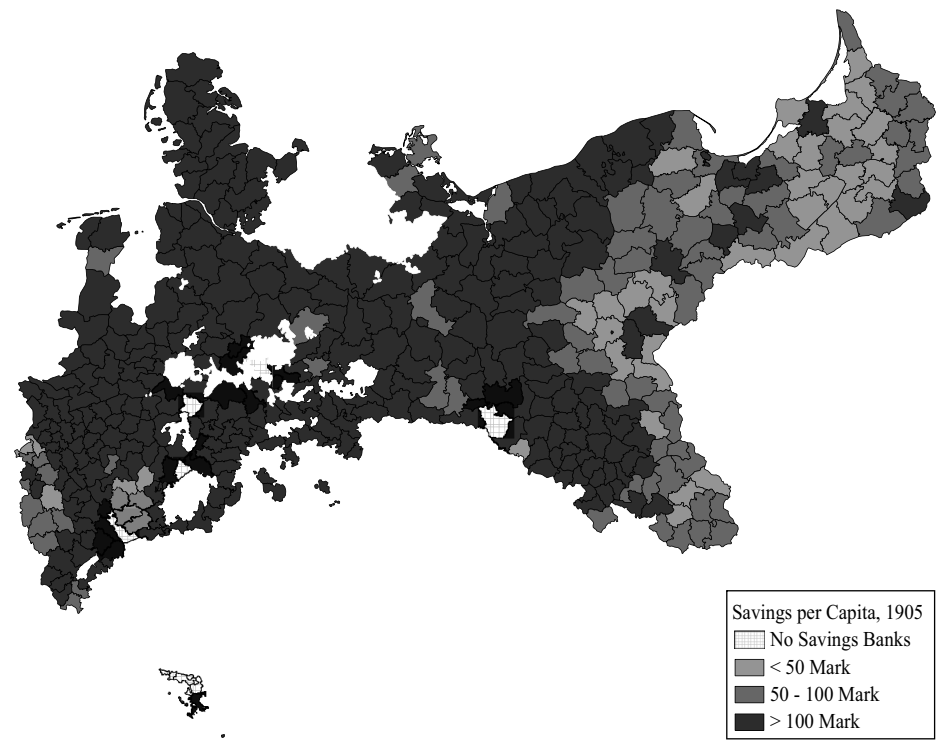

FIGURE 2

SAVINGS PER CAPITA, 1905

Notes: Darker colors correspond to higher savings per capita.

Source: See Table B.1 in the Online Appendix. 


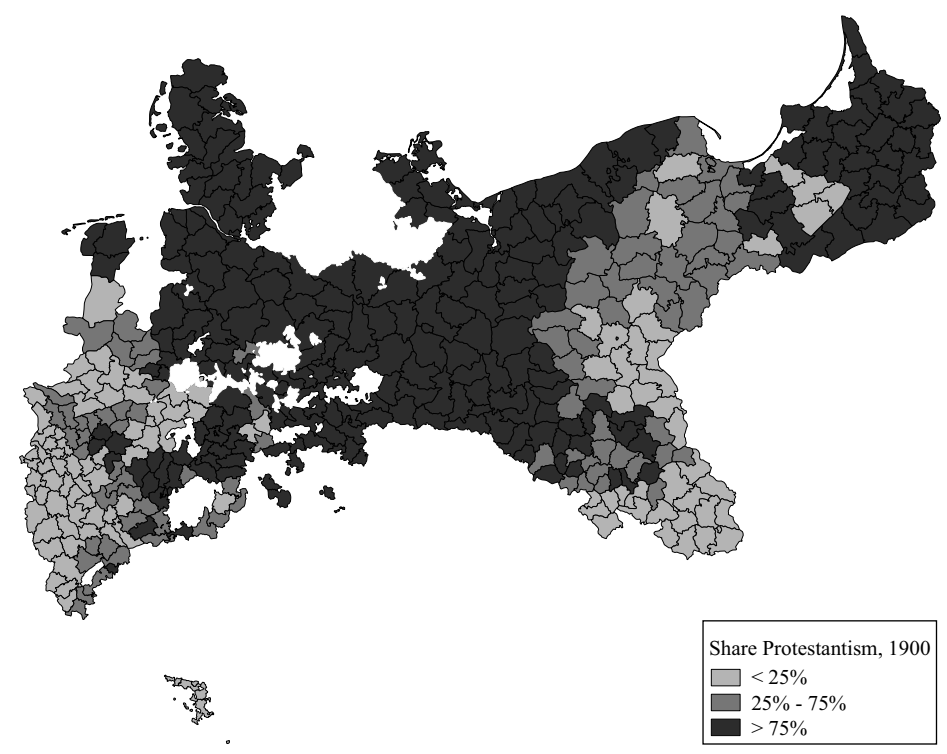

FIGURE 3

PROTESTANTISM, 1900

Notes: Darker colors correspond to a higher share of Protestants.

Source: See Table B.1 in the Online Appendix.

other religions beside Catholics and Protestants. ${ }^{5}$ We prefer pooled OLS regressions because there is only limited time variation in our main independent variable, the share of Protestants. We refer to Table B.1 in the Online Appendix for further information on our data. To control for income per capita, we combine sector-level employment statistics for each county with sector-level national wage data. To account for variations in sector-level wages across counties, we weight our income variable with county-level data for wages of day laborers. If not noted otherwise, we use robust standard errors clustered at the province level to take spatial correlation into account. ${ }^{6}$ Descriptive statistics are provided in Table 1.

In order to estimate the effect of Protestantism on economic outcomes, we need an instrument to isolate exogenous variation in the share of Protestants in nineteenth-century Prussia. As argued in the second section, the possibility of reversed causality, omitted variables, or both

\footnotetext{
${ }^{5}$ In order to differentiate between different Protestant denominations, we use census data from 1871 (Königlich Statistisches Bureau 1875), which includes information on Protestant Reformist and other Protestants. Note that less than 1 percent of the Prussian Population were Reformists.

${ }^{6}$ On the role of spatial correlation see Kelly (2019) and Colella, Lalive, Sakalli and Thoenig (2020).
} 
TABLE 1

DESCRIPTIVE STATISTICS

\begin{tabular}{|c|c|c|c|c|c|}
\hline & 1875 & 1880 & 1890 & 1900 & 1905 \\
\hline \multicolumn{6}{|l|}{ Savings } \\
\hline Savings per capita & $\begin{array}{c}42.34 \\
(59.83)\end{array}$ & $\begin{array}{c}64.77 \\
(83.40)\end{array}$ & $\begin{array}{c}94.63 \\
(105.86)\end{array}$ & $\begin{array}{c}153.0 \\
(147.83)\end{array}$ & $\begin{array}{c}206.1 \\
(179.54)\end{array}$ \\
\hline $\begin{array}{l}\text { Savings per capita, } \\
\text { and Polish credit cooperatives }\end{array}$ & & & & & $\begin{array}{c}207.0 \\
(179.03)\end{array}$ \\
\hline Number savings banks & $\begin{array}{l}2.306 \\
(2.59)\end{array}$ & $\begin{array}{l}2.795 \\
(2.89)\end{array}$ & $\begin{array}{l}3.136 \\
(3.16)\end{array}$ & $\begin{array}{l}3.592 \\
(3.70)\end{array}$ & $\begin{array}{l}3.601 \\
(3.15)\end{array}$ \\
\hline \multicolumn{6}{|l|}{ Religion } \\
\hline Share Protestants & $\begin{array}{c}64.61 \\
(37.71)\end{array}$ & $\begin{array}{l}64.46 \\
(37.59)\end{array}$ & $\begin{array}{c}64.03 \\
(37.31)\end{array}$ & $\begin{array}{c}63.72 \\
(36.90)\end{array}$ & $\begin{array}{c}63.44 \\
(36.57)\end{array}$ \\
\hline Share other religions & $\begin{array}{l}1.327 \\
(1.30)\end{array}$ & $\begin{array}{l}1.329 \\
(1.23)\end{array}$ & $\begin{array}{l}1.184 \\
(1.09)\end{array}$ & $\begin{array}{l}1.091 \\
(1.00)\end{array}$ & $\begin{array}{l}1.060 \\
(0.97)\end{array}$ \\
\hline \multicolumn{6}{|l|}{ Nation } \\
\hline Share German speaking & $\begin{array}{l}87.83 \\
(24.62)\end{array}$ & $\begin{array}{c}87.83 \\
(24.62)\end{array}$ & $\begin{array}{c}87.83 \\
(24.62)\end{array}$ & $\begin{array}{c}87.90 \\
(24.18)\end{array}$ & $\begin{array}{l}87.90 \\
(24.18)\end{array}$ \\
\hline \multicolumn{6}{|l|}{ Further Controls } \\
\hline Income per capita & $\begin{array}{c}313.5 \\
(107.11)\end{array}$ & $\begin{array}{c}313.5 \\
(107.11)\end{array}$ & $\begin{array}{c}421.5 \\
(134.93)\end{array}$ & $\begin{array}{c}529.5 \\
(166.95)\end{array}$ & $\begin{array}{c}583.5 \\
(183.86)\end{array}$ \\
\hline Share urban population & $\begin{array}{c}26.96 \\
(18.33)\end{array}$ & $\begin{array}{c}27.86 \\
(18.43)\end{array}$ & $\begin{array}{c}29.23 \\
(19.22)\end{array}$ & $\begin{array}{c}31.11 \\
(19.76)\end{array}$ & $\begin{array}{c}32.12 \\
(19.98)\end{array}$ \\
\hline Share men above the age of 14 & $\begin{array}{l}65.97 \\
(3.61)\end{array}$ & $\begin{array}{l}65.57 \\
(3.24)\end{array}$ & $\begin{array}{l}64.78 \\
(2.99)\end{array}$ & $\begin{array}{l}64.69 \\
(3.53)\end{array}$ & $\begin{array}{l}65.03 \\
(3.67)\end{array}$ \\
\hline Average household size & $\begin{array}{l}4.741 \\
(0.34)\end{array}$ & $\begin{array}{l}4.790 \\
(0.35)\end{array}$ & $\begin{array}{l}4.734 \\
(0.38)\end{array}$ & $\begin{array}{l}4.700 \\
(0.42)\end{array}$ & $\begin{array}{l}4.702 \\
(0.45)\end{array}$ \\
\hline$\overline{\mathrm{N}}$ & 434 & 434 & 434 & 434 & 434 \\
\hline
\end{tabular}

Notes: Standard deviation in parentheses. Due to lack of data on employment statistics prior to 1882 , we assume the same values for 1875 as for 1882 . Our results do not change if we exclude 1875 from our analysis.

Source: See Table B.1 in the Online Appendix.

has already been raised by Weber (1904/1905) himself. We do not think that there is an instrument for Protestantism at the county level in our historical setting, which would fully satisfy the exclusion restriction. But we think that it is important to limit the influence of potential violations of the exclusion restriction as far as possible. Our preferred approach is to follow Spenkuch (2017) in using the idiosyncratic element of religious denomination as of 1624, the "normal year" for the Peace of Westphalia. All signatories of the peace treaty of 1648 agreed to accept the confessional situation as it prevailed in 1624, in particular, not to force subjects to 
change their faith along with the faith of their ruler thereafter (Kampmann 2008, p. 176ff). This decision had a strong historical legacy (Schilling 1994, pp. 99ff). The main idea of Spenkuch's instrument is to regress Protestant in 1624 at the county level on predictors thereof, identified by Cantoni (2012) (latitude, contribution to Reichsmatrikel, distance to Wittenberg) and Rubin (2014) (existence of printing press) for counties in the former Holy Roman Empire (HRE). Distance to Wittenberg is also used for the construction of our IV, because distance to the powerful state of Saxony may have played a role in strategic neighborhood interactions (Cantoni 2012, pp. 517-18). The residual of that regression is then used as instrumental variable.

The issue of reverse causation is addressed by using an instrument with a 200-year lag. By construction, the residual from this regression reflects factors that affected the probability of a county to be Protestant in 1624, but were orthogonal to any of these controls. For example, the residual could reflect a role for military campaigns, dynastic relations, marriage policies, or historical accidents. ${ }^{7}$ With this approach we directly address the problem of potential violations of the exclusion restriction, regarding the influence of persistent differences in economic development, or local characteristics such as ethnicity.

In particular, this approach has two main advantages in order to deal with ethnicity as a confounding factor. First, the IV only includes counties that were part of the Holy Roman Empire, which reduces ethnic heterogeneity in our sample (but does not eliminate all of it). ${ }^{8}$ Second, the control for distance to Wittenberg in combination with a control variable for latitude also helps to reduce the effect of ethnic heterogeneity, because differences in ethnicity have a clear geographical pattern (compare Figure 3 and 4). Overall, the correlation between our instrumental variable and the share of German-speaking population is low (0.07) and insignificant.

The most prominent alternative to Spenkuch (2017) is the idea of Becker and Woessmann (2009) to use distance to Wittenberg directly as an IV for religious denomination. Such an approach, just like any other distancebased instrument is likely to violate the exclusion restriction, given the geography of differences in ethnicity. ${ }^{9}$ For instance, the correlation between distance to Wittenberg and share of German-speaking population is quite

\footnotetext{
${ }^{7}$ Since the reformation, religion was a major factor for dynastic marriage policy, see, for example, Duchardt (2001) or Schönpflug (2013).

${ }^{8}$ Hence, with our instrument we exclude several counties in the eastern districts Bromberg, Danzig, Gumbinnen, Königsberg, Köslin, Marienwerder, Posen as well as some counties in the northern district Schleswig-Holstein.

${ }^{9}$ Of the 50 counties furthest from Wittenberg 44 are in the eastern provinces and only 6 are in the southwest of Prussia.
} 


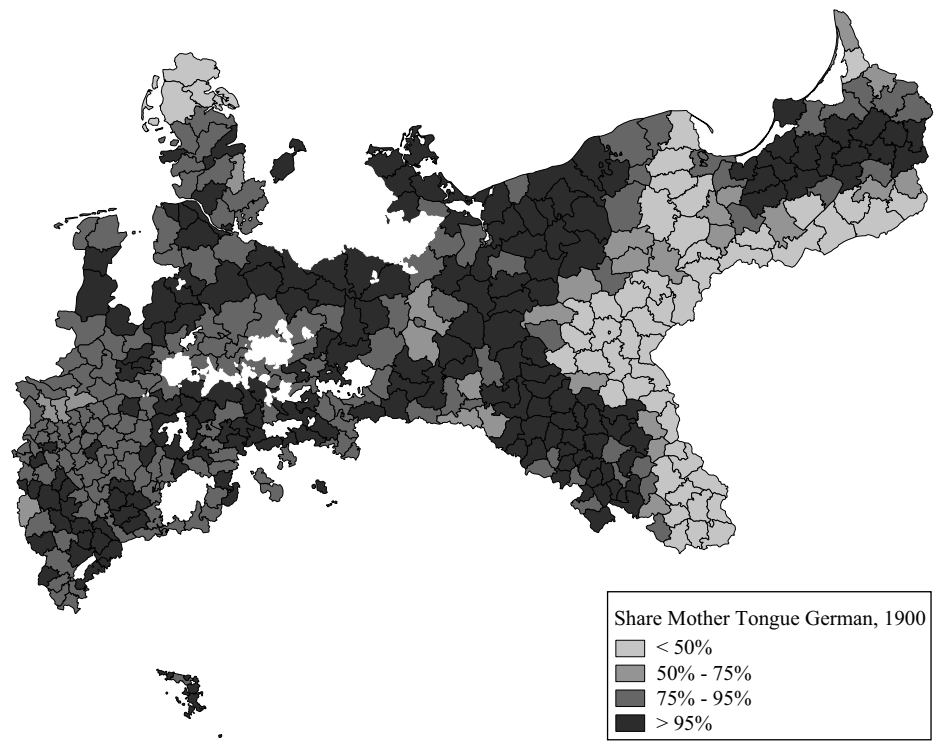

FIGURE 4

MOTHER TONGUE GERMAN, 1890

Notes: Darker colors correspond to a higher share of German speakers in the population. Source: See Table B.1 in the Online Appendix.

high (-0.35) and significant (both for the full sample and a sample limited to the HRE). The correlation is actually similar in size to the correlation between distance to Wittenberg and the share of Protestants $(-0.37)$.

As with any IV, we cannot rule out that our residual approach still suffers from violations of the exclusion restriction. But we have formally tested whether a violation of the exclusion restriction would affect our results, following Conley, Hansen, and Rossi (2012). The test indicates that our approach is quite robust, while the alternative IV would be very sensitive to a violation of the exclusion restriction. ${ }^{10}$

Based on our discussion, we estimate the following two-stage least squares model.

$$
\begin{gathered}
\operatorname{Prot}_{i t}=\alpha_{2}+\beta_{2} \text { ResidualProtestant } 1624_{i}+X_{i t}^{\prime} \gamma_{2}+\varepsilon_{2 i t} \\
\operatorname{Sav}_{i t}=\alpha_{3}+\beta_{3} \widehat{\operatorname{Prot}_{i t}}+X_{i t}^{\prime} \gamma_{3}+\varepsilon_{3 i t}
\end{gathered}
$$

${ }^{10}$ Following Karadja and Prawitz (2019), if we allow a direct negative standardized effect of distance to Wittenberg on literacy of -0.05 , the coefficient for Protestantism becomes insignificant. Note that the standardized reduced form effect of distance to Wittenberg is around -0.37 . Thus, if we allow for only slight violations of the exclusion restriction, the result already turns insignificant. If we rely on our preferred instrument, this is not the case. Here, we can allow for a direct effect of more than half of the standardized reduced form effect and still find significant effects. 
In the next step, we test for the effect of Protestantism on literacy rates, as suggested by Becker and Woessmann (2009). They argued that Weber was mistaken to suggest that Protestant attitudes mattered, but that instead Protestantism helped spread the Bible and the ability to read (and write). This way Protestantism may have had an effect on literacy and thereby on economic development. In contrast to our data for savings, literacy rates are only available for one cross-section in 1871, hence we run the following specification

$$
\text { Lit }_{i}=\alpha_{4}+\beta_{4} \text { Prot }_{i}+X_{i}^{\prime} \gamma_{4}+\varepsilon_{4 i}
$$

where Lit $_{i}$ is the share of literates in a county's population aged 10 or older, Prot $_{i}$ is the share of Protestants in the county, and $X_{i}$ is the same set of demographic control variables as used in Becker and Woessmann (2009). ${ }^{11}$

$$
\begin{gathered}
\text { Prot }_{i}=\alpha_{5}+\beta_{5} \text { ResidualProtestant } 1624_{i}+X_{i}^{\prime} \gamma_{5}+\varepsilon_{5 i} \\
\text { Lit }_{i}=\alpha_{6}+\beta_{6}{\widehat{\operatorname{Prot}_{i}}}+X_{i}^{\prime} \gamma_{6}+\varepsilon_{6 i}
\end{gathered}
$$

What is more important, given the potential pitfalls of OLS and IV regressions in our context, we provide direct statistical evidence on the difference in literacy rates between Catholics and Protestants within counties. We use a cross table on literacy by religion, which was provided by the Königlich Statistisches Bureau (1875), digitalized by Galloway (2007), but largely neglected in the literature so far. ${ }^{12}$

Third, we test for the role of ethnic differences. We include the share of people whose mother tongue is German as an indicator for ethnic differences. Figure 4 shows the geographic distribution of the share of people with German as their mother tongue. Minorities were mainly concentrated in the eastern provinces as well as in the northern part close to the Danish border. In addition, there is also a smaller Polish minority in the Ruhr area, the so-called Ruhrpolen (Ruhr Poles). Note that this variable is available for the full sample only from 1890 onwards. In 1890, German was the mother tongue of 87.8 percent of the population in Prussia, Polish for 9.6 percent, and other languages (e.g., Danish) for 2.6 percent. We will use this information for all years and assume that it does not vary

\footnotetext{
${ }^{11}$ Note that there is no indication that the census was biased towards German speaking. The question in the census asked whether people aged 10 or older were able to read and speak. It did not specifically ask about the ability to speak German (Bureau des Ministeriums des Innern 1871).

12 Unfortunately, data on literacy by ethnic nationality is not available.
} 
over time. ${ }^{13}$ Comparing Figures 3 and 4 show some correlation between religious denomination and ethnic group, especially in the eastern part of Prussia. However, there is considerable variation in terms of religious denomination in the ethnically homogeneous western parts of Prussia, for example, in the Rhine Province.

Similar to religion, ethnic differences might also be endogenous. In order to circumvent this problem, we will show our results including and excluding the eastern provinces East and West Prussia, Poznan, and Silesia. This also has the advantage that we avoid possible multicollinearity between religious denomination and ethnic groups in the eastern regions, which makes it difficult to disentangle the effect between the two variables. The remaining parts of Germany show very large variation in terms of religious denomination with quite small ethnic minorities, which should be sufficient to identify an effect of Protestantism on economic outcomes.

A specific problem would arise with regard to our data from savings banks, if the Polish minority would consider these banks as German institutions and prefer to deposit their savings elsewhere. There is no evidence for institutional barriers for the Polish minority to get access to the savings banks (Trende 1957, p. 93). But there has been a contemporary discussion on this and evidence that Polish credit cooperatives competed for Polish savings with growing success, especially after the turn of the century (Bernhard 1907, p. 244, see, also, Guinnane 2001). This could obviously bias our results towards finding an effect of ethnic differences on saving, because we would underestimate savings from the Polish community. To deal with this we collected data on the deposits of Polish credit cooperatives at the county level as of 1905 for the two provinces in Prussia with the highest share of Polish speakers (and correspondingly lowest share of German speakers), Poznan and West Prussia. The data comes from the balance sheets of all 225 credit cooperatives that were members of the "Association of Polish Economic Cooperatives in the Provinces of Poznan and West Prussia," and were published by Prussian authorities (see Suesse and Wolf 2020, Appendix G). ${ }^{14}$ Given that the vast majority of Polish savings were deposited at Polish credit cooperatives as argued by Bernhard (1907, p. 404), the addition of savings deposits at Polish credit cooperatives to savings deposits at savings banks should correct

\footnotetext{
${ }^{13}$ For a large subsample, data is available for 1867. Comparing the data from 1867 and 1890 shows no major deviations. Thus, it seems plausible to use the data from 1890 for 1875 and the following years.

${ }^{14}$ Similar data for East Prusia and Silesia, which also had high shares of Polish speakers do not exist, but we can show that our results are robust to their exclusion (Table 4, Cols. 3 and 6).
} 
for such a potential bias. Note that including saving deposits at Polish credit cooperatives matters for total savings in West Prussia and Poznan, for example, for Poznan this addition leads to an increase in total savings per capita from $73 \mathrm{RM}$ to $84 \mathrm{RM}$.

\section{RESULTS}

\section{Testing the "Common Interpretation": OLS}

Let us start with some simple correlations between the share of Protestants and the share of Germans with income, savings, and literacy rates. ${ }^{15}$ For this, we run plain OLS regressions with labor income per capita (1875-1905), savings per capita (1875-1905), income per capita measured by income tax statistics (1871), as well as literacy rates (1871) as outcome variables. Table 2 provides some first suggestive evidence on our three hypotheses. Protestantism does not seem to be strongly correlated with savings per capita nor with labor income per capita. There is a correlation between Protestantism and literacy rates, but a much stronger one between the share of German speakers and literacy rates (see Table 2, Panel 4, Column 2). And, more generally, we find that the standardized coefficient on the share of German speakers is larger for all outcomes than the one on the share of Protestants. But correlation is not causation, so we need to turn to an IV analysis.

\section{Causal Effects on Savings}

To get as close as possible to the thrust of Weber's ideas, we first test for savings behavior as a mechanism for the "common interpretation." Table 3 provides details on the relationship between savings per capita and religion from pooled OLS and two-stage least squares (2SLS) regressions. The results do not support the hypothesis according to which Protestants have a higher savings per capita than Catholics due to a specific work ethic and ascetic lifestyle. This "non-result" holds independent of whether we include counties in eastern districts or not (Columns 1 and 2) and whether we control for labor income per capita (Columns 3 and 4). As expected, labor income per capita is positively correlated with savings per capita. In additional regressions (reported in the Online Appendix in Table A.1) we allow for heterogeneous effects for reformed and other Protestants. We do not find support for the idea

\footnotetext{
${ }^{15}$ The replication files are provided in Kersting, Wohnsiedler, and Wolf (2020).
} 
TABLE 2

GERMAN SHARE, PROTESTANTISM, AND ECONOMIC OUTCOMES

\begin{tabular}{|c|c|c|}
\hline & (1) & (2) \\
\hline \multicolumn{3}{|c|}{ Panel 1: Savings per Capita, 1875-1905 } \\
\hline Share Protestants & $\begin{array}{c}0.042 \\
(0.075)\end{array}$ & $\begin{array}{c}0.021 \\
(0.085)\end{array}$ \\
\hline Share German speaking & & $\begin{array}{c}0.095 \\
(0.054)\end{array}$ \\
\hline Further controls & Yes & Yes \\
\hline $\mathrm{N}$ & 2,170 & 2,170 \\
\hline$R^{2}$ & 0.287 & 0.293 \\
\hline \multicolumn{3}{|c|}{ Panel 2: Labor Income per Capita, 1875-1905 } \\
\hline Share Protestants & $\begin{array}{l}-0.054 \\
(0.081)\end{array}$ & $\begin{array}{l}-0.077 \\
(0.077)\end{array}$ \\
\hline Share German speaking & & $\begin{array}{l}0.112 * \\
(0.059) \\
\end{array}$ \\
\hline Further controls & Yes & Yes \\
\hline $\mathrm{N}$ & 2,170 & 2,170 \\
\hline$R^{2}$ & 0.370 & 0.379 \\
\hline \multicolumn{3}{|c|}{ Panel 3: Income Tax Revenue per Capita, 1871} \\
\hline Share Protestants & $\begin{array}{l}0.170^{*} \\
(0.091)\end{array}$ & $\begin{array}{c}0.129 \\
(0.095)\end{array}$ \\
\hline Share German speaking & & $\begin{array}{c}0.244 \\
(0.160) \\
\end{array}$ \\
\hline Further controls & Yes & Yes \\
\hline $\mathrm{N}$ & 426 & 426 \\
\hline$R^{2}$ & 0.332 & 0.336 \\
\hline \multicolumn{3}{|l|}{ Panel 4: Literacy, 1871} \\
\hline Share Protestants & $\begin{array}{c}0.0992 * * * \\
(0.010)\end{array}$ & $\begin{array}{c}0.0615 * * * \\
(0.008)\end{array}$ \\
\hline Share German speaking & & $\begin{array}{c}0.221 * * * \\
(0.014)\end{array}$ \\
\hline Further controls & Yes & Yes \\
\hline $\mathrm{N}$ & 452 & 452 \\
\hline$R^{2}$ & 0.737 & 0.831 \\
\hline
\end{tabular}

Notes: In Panel 1 and 2 standardized beta coefficients. Standard errors in parentheses. Robust standard errors clustered at the province level. Further controls included in Panel 1 and 2: number of savings banks, share working men above the age of 14, share urban population, average household size, share other religions, dummy for counties without a savings bank. Further controls included in Panel 3 and 4: percent age below 10, percent Jews, percent females, percent born in municipality, percent of Prussian origin, average household size, population size ( $\log$ ), population growth 1867-1871 (in percent), percent missing education info, percent blind, percent deaf-mute, percent insane. ${ }^{*} \mathrm{p}<0.1,{ }^{* *} \mathrm{p}<0.05, * * * \mathrm{p}<0.01$.

Source: See Table B.1 in the Online Appendix. 
TABLE 3

SAVINGS PER CAPITA, 1875-1905

\begin{tabular}{|c|c|c|c|c|}
\hline & (1) & (2) & (3) & (4) \\
\hline Panel 1: OLS & \multicolumn{4}{|c|}{ Dep. Var. Savings per Capita } \\
\hline \multirow[t]{2}{*}{ Share Protestants } & 0.012 & 0.022 & 0.033 & 0.065 \\
\hline & $(0.079)$ & $(0.102)$ & $(0.081)$ & $(0.103)$ \\
\hline \multirow[t]{2}{*}{ Income per capita } & & & $0.350 * * *$ & $0.316^{* * *}$ \\
\hline & & & $(0.068)$ & $(0.072)$ \\
\hline$R^{2}$ & 0.280 & 0.245 & 0.351 & 0.308 \\
\hline Panel 2: Second Stage & \multicolumn{4}{|c|}{ Dep. Var. Savings per Capita } \\
\hline \multirow[t]{2}{*}{ Share Protestants } & -0.034 & -0.029 & -0.057 & -0.064 \\
\hline & $(0.101)$ & $(0.183)$ & $(0.110)$ & $(0.193)$ \\
\hline \multirow[t]{2}{*}{ Income per capita } & & & $0.342 * * *$ & $0.297 * *$ \\
\hline & & & $(0.072)$ & $(0.084)$ \\
\hline Panel 3: First Stage & \multicolumn{4}{|c|}{ Dep. Var. Protestantism } \\
\hline \multirow[t]{2}{*}{ Residual decision 1624} & $0.429 * * *$ & $0.288^{* * *}$ & $0.432 * * *$ & $0.294 * * *$ \\
\hline & $(0.083)$ & $(0.048)$ & $(0.081)$ & $(0.045)$ \\
\hline \multirow[t]{2}{*}{ Income per capita } & & & -0.109 & $-0.162^{*}$ \\
\hline & & & $(0.092)$ & $(0.080)$ \\
\hline$R^{2}$ & 0.324 & 0.392 & 0.331 & 0.409 \\
\hline Including eastern provinces & Yes & No & Yes & No \\
\hline Further controls & Yes & Yes & Yes & Yes \\
\hline F-statistic excluded instruments & 26.65 & 36.26 & 28.73 & 42.32 \\
\hline $\mathrm{N}$ & 1,830 & 1,355 & 1,830 & 1,355 \\
\hline
\end{tabular}

Notes: Standardized beta coefficients. Standard errors in parentheses. Robust standard errors clustered at the province level. Eastern provinces include East and West Prussia, Poznan, and Silesia. Further controls include number of savings banks, share working men above the age of 14, share urban population, average household size, share other religions, dummy for counties without a savings bank.

$* \mathrm{p}<0.1, * * \mathrm{p}<0.05, * * * \mathrm{p}<0.01$.

Source: See Table B.1 in the Online Appendix.

that reformed Protestants have higher savings per capita or higher saving rates. If anything, reformed Protestants seem to have lower savings per capita. We conclude that we have to reject hypothesis H1, based on our evidence for Prussia after 1871. At the time of Weber's writing, there is no evidence that Protestants would have saved more than Catholics.

Our reading of Weber's PE suggests that we should not be surprised by this. Given the context of rising nationalism and ethnic tensions especially between Germans and Poles, we might wonder instead if there were substantial differences in saving behavior between ethnic groups. 
A problem here is that our data from savings banks might systematically underestimate Polish savings, if Poles indeed started to prefer Polish credit cooperatives for their saving deposits as argued above. However, this effect is unlikely to drive our results. First, it is noteworthy that we do not find any significant relationship between savings and Protestantism in Table 3 (Column 1), even though there might be a bias against savings by Poles, which were predominantly Catholic. Next, we can directly correct for such a bias with data on saving deposits from Polish credit cooperatives, which we could find for 1905. In Table 4, we rerun our regression from Table 3 with a control variable for the share of German speakers (Columns 1 and 2). We see that ethnic differences are strongly correlated with saving behavior, while religious differences are not. If we add saving deposits from Polish credit cooperatives to our dependent variable this result remains virtually unchanged (Columns 4-6 in Table 4). Given that we have the data for Polish savings only for counties in the Provinces of Poznan and West Prussia, we show that our main findings remain qualitatively unchanged, if we drop the other two provinces with large Polish populations, Silesia and East Prussia (Table 4, Col. 3 compared to Col. 6). ${ }^{16}$ For each specification, the coefficient on German speakers declines very slightly but stays large and significant. ${ }^{17}$ It seems unlikely that this effect is due to a Polish bias against savings banks. In any case, our results suggest that ethnic differences were strongly correlated with economic outcomes (H3).

\section{Causal Effects on Literacy Rates}

While there is no evidence for late nineteenth-century Prussia that Protestants had higher savings per capita, it could still be that Protestantism mattered for economic development via some other mechanism, such as literacy rates as argued by Becker and Woessmann (2009).

As a first step to test hypothesis $\mathrm{H} 2$, we analyze a cross table, which includes information on literacy by religion as of 1871 . This evidence is essential, as it directly shows how literacy rates differed between

\footnotetext{
${ }^{16}$ The shares of German speakers in the population (1890) were 38.88 percent (Poznan), 61.87 percent (West Prussia), 76.38 percent (East Prussia), 77.06 percent (Silesia), 81.22 percent in Schleswig-Holstein, and around 98 percent in all remaining provinces of Prussia.

${ }^{17}$ Given that our instrument excludes some counties in the eastern provinces, we run further OLS regressions in Online Appendix Table A.2. Here we include all Prussian counties, except the provinces of Silesia and East Prussia where we do not have additional data on Polish savings. As in Table 4 before, we find a strong positive correlation between the share of German speaking population and the savings per capita. The coefficient of share of German-speaking population declines slightly but stays highly significant, once we control for Polish savings.
} 
TABLE 4

SAVINGS PER CAPITA AND ETHNIC DIFFERENCES, 1905

\begin{tabular}{|c|c|c|c|c|c|c|}
\hline & (1) & (2) & (3) & (4) & (5) & (6) \\
\hline Panel 1: OLS & \multicolumn{3}{|c|}{ Dep. Var. Savings p.c. } & \multicolumn{3}{|c|}{ + Pol. Credit Coop. } \\
\hline \multirow[t]{2}{*}{ Share Protestants } & 0.067 & 0.069 & 0.081 & 0.067 & 0.069 & 0.081 \\
\hline & $(0.085)$ & $(0.085)$ & $(0.116)$ & $(0.085)$ & $(0.085)$ & $(0.116)$ \\
\hline \multirow[t]{2}{*}{ Share German speaking } & $0.121 * *$ & $0.116 * *$ & $0.113 * * *$ & $0.121 * *$ & $0.116^{* *}$ & $0.112 * * *$ \\
\hline & $(0.041)$ & $(0.049)$ & $(0.027)$ & $(0.041)$ & $(0.049)$ & $(0.027)$ \\
\hline \multirow[t]{2}{*}{ Income per capita } & & 0.033 & -0.051 & & 0.032 & -0.052 \\
\hline & & $(0.092)$ & $(0.078)$ & & $(0.092)$ & $(0.078)$ \\
\hline Further controls & Yes & Yes & Yes & Yes & Yes & Yes \\
\hline$R^{2}$ & 0.291 & 0.292 & 0.252 & 0.291 & 0.292 & 0.251 \\
\hline Panel 2: Second Stage & \multicolumn{3}{|c|}{ Dep. Var. Savings p.c. } & \multicolumn{3}{|c|}{ + Pol. Credit Coop. } \\
\hline \multirow[t]{2}{*}{ Share Protestants } & -0.011 & -0.013 & -0.069 & -0.012 & -0.014 & -0.070 \\
\hline & $(0.107)$ & $(0.103)$ & $(0.181)$ & $(0.107)$ & $(0.104)$ & $(0.181)$ \\
\hline \multirow[t]{2}{*}{ Share German speaking } & $0.129 * *$ & $0.126^{* *}$ & $0.129 * * *$ & $0.128 * *$ & $0.125 * *$ & $0.128 * * *$ \\
\hline & $(0.041)$ & $(0.050)$ & $(0.035)$ & $(0.040)$ & $(0.050)$ & $(0.035)$ \\
\hline \multirow[t]{2}{*}{ Income per capita } & & 0.023 & -0.080 & & 0.023 & -0.080 \\
\hline & & $(0.095)$ & $(0.096)$ & & $(0.095)$ & $(0.096)$ \\
\hline Panel 3: First Stage & \multicolumn{3}{|c|}{ Dep. Var. Protestantism } & & & \\
\hline \multirow[t]{2}{*}{ Residual decision 1624} & $0.407 * * *$ & $0.414 * * *$ & $0.262 * * *$ & $0.407 * * *$ & $0.414 * * *$ & $0.262 * * *$ \\
\hline & $(0.096)$ & $(0.090)$ & $(0.063)$ & $(0.096)$ & $(0.090)$ & $(0.063)$ \\
\hline \multirow[t]{2}{*}{ Share German speaking } & 0.065 & 0.087 & 0.063 & 0.065 & 0.087 & 0.063 \\
\hline & $(0.104)$ & $(0.094)$ & $(0.067)$ & $(0.104)$ & $(0.094)$ & $(0.067)$ \\
\hline \multirow[t]{2}{*}{ Income per capita } & & -0.148 & -0.223 & & -0.148 & -0.223 \\
\hline & & $(0.159)$ & $(0.138)$ & & $(0.159)$ & $(0.138)$ \\
\hline$R^{2}$ & 0.331 & 0.343 & 0.424 & 0.331 & 0.343 & 0.424 \\
\hline $\begin{array}{l}\text { Including Silesia and } \\
\text { eastern Prussia }\end{array}$ & Yes & Yes & No & Yes & Yes & No \\
\hline Further controls & Yes & Yes & Yes & Yes & Yes & Yes \\
\hline $\begin{array}{l}\text { F-statistic excluded } \\
\text { instruments }\end{array}$ & 17.85 & 21.01 & 17.20 & 17.85 & 21.01 & 17.20 \\
\hline $\mathrm{N}$ & 366 & 366 & 281 & 366 & 366 & 281 \\
\hline
\end{tabular}

Notes: Standardized beta coefficients. Standard errors in parentheses. Robust standard errors clustered at the province level. Further controls include number of savings banks, share working men above the age of 14 , share urban population, average household size, share other religions, dummy for counties without savings banks. $* \mathrm{p}<0.1, * * \mathrm{p}<0.05, * * * \mathrm{p}<0.01$. In Columns (1) and (2) we include savings per capita from savings banks, in Columns (3) to (5) we add deposits from Polish credit cooperatives.

Source: See Table B.1 in the Online Appendix. 
Protestants and Catholics within counties. It is quite surprising that this has been largely ignored in the existing empirical literature. In Figure 5 we plot the share of Protestants and the share of Protestant literates in literates. Each dot represents one county. The intuition is the following: a dot right to the 45-degree line indicates that Protestants are over-proportionally literate in this county. Panel (a) in Figure 5 shows that there is some evidence that Protestants indeed are over-proportionally literate. However, most counties in which Protestants are over-proportionally literate are located in the eastern part of Prussia with a large Polish-speaking population as seen in Panel (b) in Figure 5. In counties excluding the eastern provinces, the relationship between Protestant literates and Protestants follows very closely a 45-degree line as shown in Panel (c) in Figure 5. The difference in literacy rates between Catholics and Protestants within counties is a mere 1.05 percentage points for the entire sample. Once we exclude the eastern provinces, this difference declines to 0.14 percentage points. Another way to illustrate this is to show the difference in the share of Protestant literates in literates and share of Protestants on a map: Figure 6 shows that the counties with over-proportional literacy of Protestants are exclusively located in the eastern part of Prussia. ${ }^{18}$

Table 5 shows the results from an OLS and IV approach to the problem. To compare to our results on savings and to the previous literature, we focus again on average literacy rates at the county level. To start with, the OLS results suggest some small but significant effect of Protestantism on average county-level literacy (Column 1). They are still smaller if we exclude the eastern provinces (Col. 2), or if we include them but control for the share of German speakers (Col. 3), and much smaller than those for German speakers. However, the OLS coefficient stays statistically significant. A possible reason for this could be a county-specific Protestant tradition of education, which could have had positive spillovers to Catholics, along the lines suggested by Becker and Woessmann (2009). ${ }^{19}$ Alternatively, the OLS result could reflect reverse causation running from literacy to Protestantism or a problem of omitted variables at the county-level as discussed in the fourth section. To address this, we

\footnotetext{
${ }^{18}$ There are only a few counties in the rest of Prussia, where this difference amounts to more than 1 percentage points. This is the case for the counties Moers, Rees, Gladbach, and Wiedenbrück. Note that even this difference is insignificant.

${ }^{19}$ In Table A.6 of the Online Appendix we exploit the cross-table data to test spill-over effects of Protestantism in Becker and Wössmann (2009). To this end, we use literacy among Catholics at the county level as our dependent variable and test, whether the share of Protestants in a county has a positive effect. The OLS regression (Panel 1) does not suggest any effect. An IV regression with distance to Wittenberg suggests a weakly significant positive effect, but only if we restrict the sample to the HRE. Using the residual of 1624 as an instrument, we do not find any effect of the share of Protestants on literacy rates among Catholics.
} 
(a) All Counties

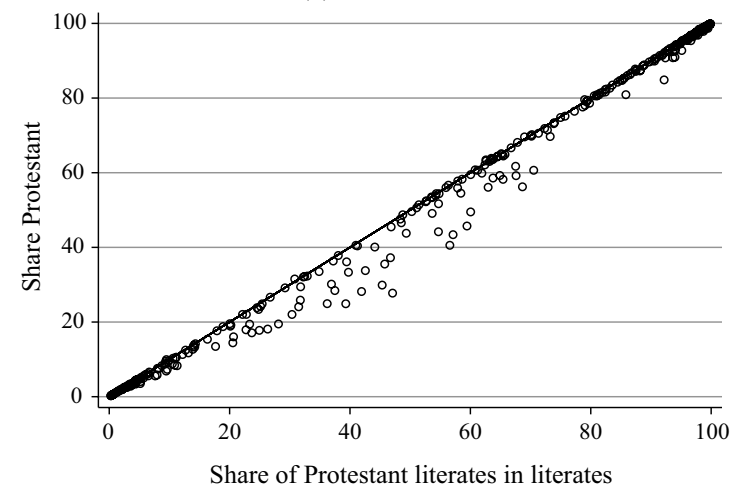

(b) Eastern Provinces

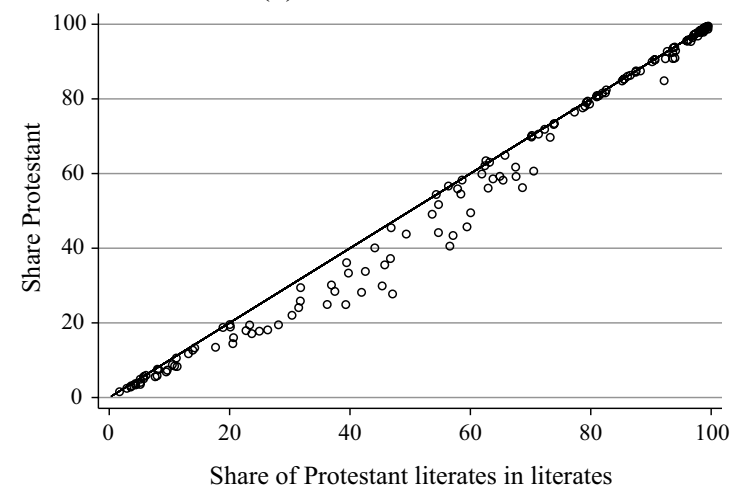

(c) Western Provinces

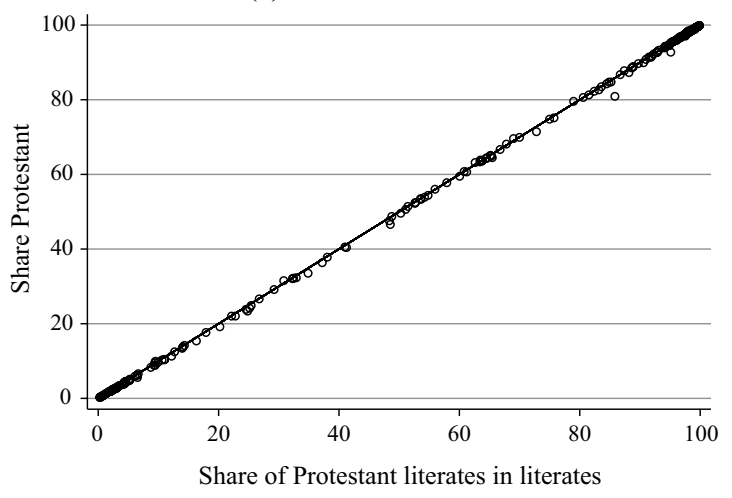

FIGURE 5

\section{LITERACY AND PROTESTANTISM, 1871}

Notes: Each dot corresponds to one county. Interpretation: protestants are over-proportionally literate in counties to the right of the 45 degree line. Eastern provinces: Poznan, Silesia, West and East Prussia.

Source: See Table B.1 in the Online Appendix. 


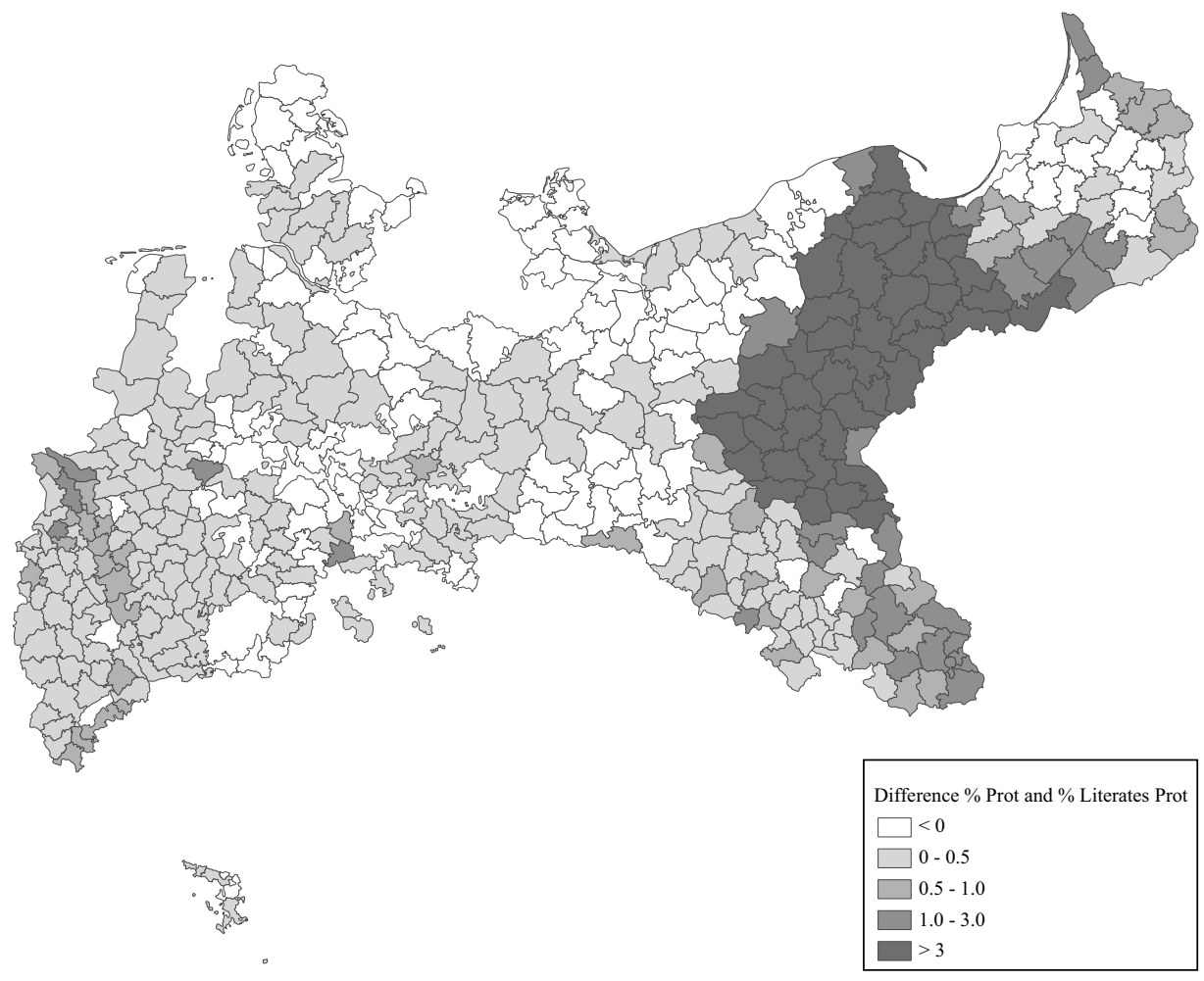

FIGURE 6

DIFFERENCE PERCENT LITERATE PROTESTANTS AMONG PROTESTANTS AND PERCENT PROTESTANTS, 1871

Notes: The maps shows for each county the difference between the share of Protestants and the share of Protestant literates in literates. The stronger Protestants are over-proportionately literate, the darker the color for this county.

Source: See Table B.1 in the Online Appendix.

need an instrument and use again the IV from Spenkuch (2017). Our findings are very much in line with the evidence from the cross table visualized in Figures 5 and 6. We find no significant positive effect of Protestantism on literacy rates (Table 5, Panel 2, Columns 1 to 3). Moreover, we have tested for the idea that Protestantism affects economic outcomes with literacy as a mediating variable but do not find much support for this (see Online Appendix C). ${ }^{20}$ In Table 5 (Column 3), we see that the effect of the share of German speakers is large and highly significant. An increase in the share of the population with German as their mother tongue by 1 percentage is associated with an increase in literacy by 0.2 percentage points. Given the

${ }^{20}$ In Online Appendix $\mathrm{C}$ we compare our results more directly with the ones from Becker and Woessmann (2009). There we replicate their findings and show how controlling for German speakers, changes in the sample and the use of distance to Wittenberg as an IV lead to the different results. 
TABLE 5

EFFECT OF PROTESTANTISM ON LITERACY, 1871

(1)

\begin{tabular}{|c|c|c|c|}
\hline Panel 1: OLS & & Var. Liter & \\
\hline Share Protestants & $\begin{array}{c}0.057 * * * \\
(0.009)\end{array}$ & $\begin{array}{l}0.033 * * \\
(0.013)\end{array}$ & $\begin{array}{c}0.040^{* * *} \\
(0.012)\end{array}$ \\
\hline Share German speaking & & & $\begin{array}{c}0.213 * * * \\
(0.036)\end{array}$ \\
\hline$\overline{R^{2}}$ & 0.610 & 0.431 & 0.735 \\
\hline Panel 2: Second Stage & & . Var. Liter & \\
\hline Share Protestants & $\begin{array}{c}0.030 \\
(0.018)\end{array}$ & $\begin{array}{c}0.031 \\
(0.017)\end{array}$ & $\begin{array}{c}0.020 \\
(0.015)\end{array}$ \\
\hline Share German speaking & & & $\begin{array}{c}0.221 * * * \\
(0.036)\end{array}$ \\
\hline Panel 3: First Stage & & Var. Protesta & \\
\hline Residual decision 1624 & $\begin{array}{c}46.088^{* * *} \\
(4.227)\end{array}$ & $\begin{array}{c}43.094 * * * \\
(3.277)\end{array}$ & $\begin{array}{c}45.369 * * * \\
(2.866)\end{array}$ \\
\hline Share German speaking & & & $\begin{array}{c}0.327 * * \\
(0.144)\end{array}$ \\
\hline$\overline{R^{2}}$ & 0.474 & 0.599 & 0.489 \\
\hline Including eastern provinces & Yes & No & Yes \\
\hline Further controls & Yes & Yes & Yes \\
\hline F-statistic excluded instruments & 246.34 & 172.95 & 250.58 \\
\hline $\mathrm{N}$ & 378 & 280 & 378 \\
\hline
\end{tabular}

Notes: Standard errors in parentheses. Robust standard errors clustered at the province level. Eastern provinces include East and West Prussia, Poznan, and Silesia. Further controls: percent age below 10, percent Jews, percent females, percent born in municipality, percent of Prussian origin, average household size, population size (log), population growth 1867-1871 (in percent), percent missing education info, percent blind, percent deaf mute, percent insane. $* \mathrm{p}<0.1, * * \mathrm{p}<0.05, * * * \mathrm{p}<0.01$.

Source: See Table B.1 in the Online Appendix.

size of this effect, ethnic differences clearly should be a control variable for the "common interpretation," notably for nineteenth-century Germany. Overall, our results show strong support for $\mathrm{H} 3$, but neither for $\mathrm{H} 1$ nor $\mathrm{H} 2$.

\section{WHY DO ETHNIC DIFFERENCES MATTER?}

Our finding on the role of ethnic differences for economic outcomes begs for some explanation. We think it unlikely that ethnicity captures any deep differences in attitudes between Germans, Poles, and other 
ethnic groups, as argued by Weber in his IL 1895. Instead, we suggest that the effects might result from the interaction between Germans and Poles. In particular, we provide some suggestive evidence on the role of discrimination against the Polish minority by the German majority and on the Polish institution building as a reaction against this discrimination. It would be beyond the scope of our paper to analyze this in detail, but we think it should be taken up by further research.

As described in the third section on the historical context of our study, tensions between nationalities increased within the German Empire after its foundation. One - or rather the major aspect of these tensions was discrimination against the large Polish minority concerning education policy. The Prussian government had pursued discriminatory policies against the Poles already before 1870 , especially restrictive language policies after 1848 (Gessinger 1991, p. 118ff). After 1870 the German government provided monetary incentives (so-called Ostmarkenzulage) for German teachers to work in the eastern provinces, which attracted especially more nationalist teachers with a mission in "Germanizing" the East (Lamberti 1989). Anecdotal evidence suggests that this had striking effects. For example, in Poznan, the largest Polish city in the Empire, the most prestigious Catholic grammar school (St. Mary Magdalene School) had 24 Polish teachers in 1870, but only 3 in 1890 and 2 in 1912 (Molik 1998, p. 22). Another result of this discriminatory policy was that the expenses per pupil were lower in the eastern provinces (Lamberti 1989). Regions in Prussia with a higher linguistic polarization, that is, especially the eastern provinces, tended to spend less for the decentralized education system (Cinnirella and Schueler 2016). Moreover, there is evidence that schools in the eastern provinces with a higher share of German-speaking pupils were preferred in terms of resources (Lamberti 1989). Another important aspect of this is higher education. In spite of decades of discussion around the subject, which started already in 1815 and intensified again after 1871, there was no university in these provinces, in contrast to the Austrian partition of Poland (with the universities of Krakow and Lwow, founded 1364 and 1661, respectively), and the Russian partition (with the university Warsaw, opened in 1815, closed in 1869). Polish speakers had to attend a university in one of the German provinces and study in German. According to Schutte (2008), the German reluctance to open a university in the Polish provinces was due to the fear of the German majority that better education might equip the Polish minority with more effective tools for resistance against discrimination and own nation building. The 1903 opening of a Royal Academy in Poznan that served some limited functions of a university (in German language) was 
accompanied by a heated debate. It was only in 1919 after Poland was re-established as a state, that the Academy was turned into a full university, which could cater for the needs of the Polish society.

This discrimination in terms of education policy had probably direct effects on educational attainment and human capital formation. Insofar as this discrimination started already before 1871, for example, in the realm of language policy and higher education, it might help to explain the differences in literacy rates around 1871 (see the discussion in Knabe 2000 , p. 162ff). Such discrimination would also have effects on earnings and incomes, but not necessarily on savings rates unless it affected savings stronger than incomes. As suggested by the literature on financial literacy, this is indeed likely to be the case (Lusardi and Mitchell 2011), but it would require a separate investigation.

Additionally, the existence of increasing national segregation in the labor market might help to explain the difference in economic outcomes. The occupational distribution can be used as an indicator for the status of different groups in a society as shown by Hsieh et al. (2013) for the United States. These authors also show that frictions in the labor markets, which can be due to discrimination, can lead to a systematic misallocation of talent with far-reaching implications for economic development. According to Hagen (1981), there were striking differences in the occupational structure between Germans and Poles. The ratio between Germans and Poles for different occupations in the province Poznan was for medical doctors 3 to 1 , veterinarians 8 to 1 , apothecaries 3 to 1 , lawyers and notaries 4 to 1 , and employees in railway and postal offices 19 to 1 . Given that the share of Polish people in Poznan was about 50 percent, these statistics show a very clear national divide in the labor market. The contemporary statistician Max Broesike (1909) provides further evidence for a sharp segregation between Poles and Germans in the labor market in the province Silesia: Poles were underrepresented in the industry sector and especially in public services. Instead, Poles were concentrated in the agricultural sector. Already from the 1860s onward were the higher ranks in the public administration of Ostelbien nearly exclusively dominated by Germans (Molik 1998). Among all academic professions, medical doctors were the most attractive for the Polish minority, also due to the relative independence from state intervention. The number of Polish doctors in the province of Poznan increased between 1872 and 1912 in absolute terms but also relative to the number of German doctors (Molik 1998). But the differences remained striking. Table A.3 in the Online Appendix provides detailed evidence on doctors for each district in the province Poznan for 1907 and shows sharp differences between 
the share of Polish doctors and the share of Polish-speaking population. To summarize, there is some evidence suggesting that anti-Polish discrimination is a potential explanation for the large differences in economic outcomes between Germans and Poles. We cannot substantiate these ideas here but think they could be fruitful avenues for future research.

\section{CONCLUSION}

We revisited the evidence for Max Weber's PE in the context in which he was writing: The German Empire before 1914. To speak with Robert Margo, this is an example why "putting the context front and center is the essence of economic history, its fundamental contribution to economics per se" (Margo 2017, p. 37). We showed that a misinterpretation of this context can easily lead to missing the main factors in the evidence, including mistaken econometric specifications. Our main argument is that the "common interpretation" of Weber's PE has largely missed his own focus on saving behavior and his anti-Polish nationalism. First, we test Weber's suggestion that Protestantism mattered due to an "ascetic compulsion to save." Using data for late nineteenth-century Prussia we can clearly reject this hypothesis. Neither in simple OLS nor in IV regressions, nor for subsamples do we find that Protestants saved more than Catholics (Tables 3 and 4). However, there is evidence that saving behavior differed between Germans and Poles (Table 4). Next, we test the hypothesis that Protestantism mattered via differences in literacy rates. We show from direct statistical evidence that such differences were negligible for the predominantly German-speaking provinces of Prussia and mattered only in the East, in regions with a large Polish minority (Figure 5). We confirm these findings using OLS and IV regressions (Table 5). Taken together, we show that economic outcomes in late nineteenth-century Prussia differed much more between ethnic groups than between religious groups.

This new empirical evidence is in line with the bulk of the historical literature, which stresses the increasing role of national conflict between Germans and national minorities towards the end of the nineteenth century, while tensions between Protestants and Catholics were abating after the end of the Kulturkampf. The German authorities used their power, in the realm of education policy and elsewhere, which were increasingly geared against the Polish minority. We provided some tentative evidence that Poles suffered from discrimination in education policies and in the labor markets. We also showed that the successful emergence of Polish 
parallel structures, such as Polish credit cooperatives used as substitutes for savings banks, are relevant in our context. On another level, we find that this is in line with a critical reading of Weber's PE, which should be understood in its historical context. Weber himself was an ardent German nationalist, and it would be naive to consider the PE only as an attempt to explain the origins of capitalism. It is certainly a founding text for sociology and cultural economics. But beyond this, it should be understood as a political intervention that aimed to provide the German political class with a "calling." On a final note, we do not want to dismiss a more abstract interpretation of Weber's writing from the perspective of empirical economics. This can be stimulating and generate valuable insights. But our evidence cautions that the "common interpretation" of Weber's PE should take nationalism and ethnic differences into consideration, in the context of nineteenth-century Germany or elsewhere.

\section{REFERENCES}

Acemoglu, Daron. Introduction to Modern Economic Growth. Princeton: Princeton University Press, 2009.

Alaoui, Larbi, and Alvaro Sandroni. "Predestination and the Protestant Ethic." Journal of the European Economic Association 16, no. 1 (2018): 45-76.

Barbalet, Jack M. "Weber's Inaugural Lecture and Its Place in His Sociology.” Journal of Classical Sociology 1, no. 2 (2001): 147-70.

-Weber, Passion and Profits: "The Protestant Ethic and the Spirit of Capitalism" in Context. Cambridge: Cambridge University Press, 2008.

Barro, Robert J., and Rachel M. McCleary. "Religion and Economic Growth across Countries.” American Sociological Review 68, no. 5 (2003): 760-81.

Bartels, Charlotte. "Top Incomes in Germany, 1871-2014." Journal of Economic History 79, no. 3 (2019): 669-707.

Bartels, Charlotte, Felix Kersting, and Nikolaus Wolf. "Testing Marx: Income Inequality, Market Concentration and Voting in Late 19th Century Germany." Humboldt University Berlin. Mimeo, 2019.

Becker, George. "Replication and Reanalysis of Offenbacher's School Enrollment Study: Implication for the Weber and Merton Theses." Journal for the Scientific Study of Religion 36, no. 4 (1997): 483-95.

Becker, Sascha O., Francesco Cinnirella, Erik Hornung, and Ludger Woessmann. "iPEHD - The ifo Prussian Economic History Database." Historical Methods: A Journal of Quantitative and Interdisciplinary History 47, no. 2 (2014): 57-66.

Becker, Sascha O., Steven Pfaff, and J. Rubin. "Causes and Consequences of the Protestant Reformation.” Explorations in Economic History, 62 (2016): 1-25.

Becker, Sascha O., and Ludger Woessmann. "Was Weber Wrong? A Human Capital Theory of Protestant Economic History." Quarterly Journal of Economics 124, no. 2 (2009): 531-96.

Belzyt, Leszet. Sprachliche Minderheiten im preußischen Staat 1815-1914. Marburg: Verlag Herder-Institut, 1998. 
Bénabou, Roland, and Jean Tirole. "Willpower and Personal Rules." Journal of Political Economy 112, no. 4 (2004): 848-86.

_. "Incentives and Prosocial Behavior." American Economic Review 96, no. 5 (2006): 1652-78.

- "Identity, Morals, and Taboos: Beliefs as Assets." Quarterly Journal of Economics 126, no. 2 (2011): 805-55.

Bernhard, Ludwig. Die Polenfrage: Das polnische Gemeinwesen im preußischen Staat. Leipzig: Duncker \& Humblot, 1907.

Broadberry, Stephen N., and Carsten Burhop. "Comparative Productivity in British and German Manufacturing before World War II: Reconciling Direct Benchmark Estimates and Time Series Projections." Journal of Economic History 67, no. 2 (2007): 315-49.

Broesike, M. "Die oberschlesischen Polen." Zeitschrift des Königlich Preussischen Statistischen Landesamts 49 (1909): 25-62.

Bureau des Ministeriums des Innern. Ministerial-Blatt für die gesammte innere Verwaltung in den Königlich Preußischen Staaten, 32. Jahrgang. Berlin: Verlag des Kaiserlichen Post-Zeitungs-Amts, 1871.

Cantoni, Davide. "Adopting a New Religion: The Case of Protestantism in 16th Century Germany." Economic Journal 122, no. 560 (2012): 502-31.

_. "The Economic Effects of the Protestant Reformation." Journal of the European Economic Association 13, no. 4 (2015): 561-98.

Cantoni, Davide, Jeremiah Dittmar, and Noam Yuchtman. "Religious Competition and Reallocation: The Political Economy of Secularization in the Protestant Reformation." Quarterly Journal of Economics 133, no. 4 (2018), 2037-96.

Cinnirella, Francesco, and Ruth Maria Schueler. "The Cost of Decentralization: Linguistic Polarization and the Provision of Education." CESifo Working Paper No. 5894, Munich, Germany, 2016.

Colella, Fabrizio, Rafael Lalive, Seyhun Orcan Sakalli, and Mathias Thoenig. "Inference with Arbitrary Clustering.” HEC University of Lausanne. Mimeo, 2020.

Conley, Timothy G., Christian B. Hansen, and Peter E. Rossi. "Plausibly Exogenous." Review of Economics and Statistics 94, no. 1 (2012): 260-72.

Delacroix, Jacques, and François Nielsen. "The Beloved Myth: Protestantism and the Rise of Industrial Capitalism in Nineteenth-Century Europe.” Social Forces 80, no. 2 (2001): 509-53.

Dippel, Christian, Andreas Ferrara, and Stephan Heblich. "ivmediate: Causal Mediation Analysis Ininstrumental Variables Regressions.” Stata Journal, forthcoming, 2020.

Dippel, Christian, Robert Gold, Stephan Heblich, and Rodrigo Pinto. "Instrumental Variables and Causal Mechanisms: Unpacking the Effect of Trade on Workers and Voters.” NBER Working Paper Series No. 23209, Cambridge, MA, 2018.

Doepke, Matthias, and Fabrizio Zilibotti. "Occupational Choice and the Spirit of Capitalism.” Quarterly Journal of Economics 123, no. 2 (2008): 747-93.

Dohmen, Thomas, Benjamin Enke, Armin Falk, David Huffmann, and Uwe Sunde. "Patience and Comparative Development." University of Bonn. Mimeo, 2018.

Duchhardt, H. "Die dynastische Heirat als politisches Signal." In Hochzeit als ritus und casus, edited by E. Bialek and J. Szafarz, 67-70. Wroclaw: Oficyna Wydawnicza, 2001.

Galloway, Patrick R. "Galloway Prussia Database 1861 to 1914," 2007, www. patrickgalloway.com. 


\section{The Protestant Ethic and the Spirit of Nationalism}

Gessinger, Joachim. "Sprachenpolitik gegenüber fremdsprachiger Bevölkerung in

Preußen im 19. Jahrhundert." In Das 19. Jahrhundert. Sprachgeschichtliche Wurzeln des heutigen Deutsch, edited by R. Wimmer, 106-24. Berlin: De Gruyter, 1991.

Graf, F. W. "The German Theological Sources and Protestant Church Politics." In Weber's Protestant Ethic: Origins, Evidence, Contexts, edited by Hartmut Lehmann and Guenther Roth, 27-50. Cambridge: Cambridge University Press, 1995.

Grant, Oliver. Migration and Inequality in Germany 1870-1913. Oxford: Oxford University Press, 2005.

Guinnane, Timothy W. "Cooperatives as Information Machines: German Rural Credit Cooperatives, 1883-1914." Journal of Economic History 61, no. 2 (2001): 366-89.

Hagen, William W. Germans, Poles, and Jews: The Nationality Conflict in the Prussian East, 1772-1914. Chicago: University of Chicago Press, 1981.

Hoffmann, Walther G. Das Wachstum der deutschen Wirtschaft seit der Mitte des 19. Jahrhunderts. Berlin: Springer, 1965.

Hornung, Erik. "Railroads and Growth in Prussia." Journal of the European Economic Association 13, no. 4 (2015): 699-736.

Hsieh, Chang-Tai, Erik Hurst, Charles I. Jones, and Peter J. Klenow. "The Allocation of Talent and U.S. Economic Growth.” NBER Working Paper No. 18693, Cambridge, MA, January 2013.

Iannaccone, Laurence R. "Introduction to the Economics of Religion." Journal of Economic Literature 36, no. 3 (1998): 1465-95.

Kaiserliches Statistisches Amt. Statistik des deutschen Reichs. Band 2. Berlin: Puttkammer \& Mühlbrecht, 1884.

- Statistik des deutschen Reichs. Band 109. Berlin: Puttkammer \& Mühlbrecht, 1897.

- Statistik des deutschen Reichs. Band 240. Berlin: Puttkammer \& Mühlbrecht, 1910.

Kampmann, Christoph. Europa und das Reich im Dreißigjährigen Krieg. Stuttgart: Kohlhammer, 2008.

Karadja, Mounir, and Erik Prawitz. "Exit, Voice, and Political Change: Evidence from Swedish Mass Migration to the United States." Journal of Political Economy 127, no. 4 (2019): 1864-925.

Kelly, Morgan. "The Standard Errors of Persistence." CEPR Discussion Paper No. 13783, London, UK, 2019.

Kersting, Felix. "Coal and Blood: Industrialization and the Rise of Nationalism in Prussia before 1914." CRC TRR 190 Rationality and Competition Discussion Paper No. 52, Munich, Germany, 2017.

Kersting, Felix, Iris Wohnsiedler, and Nikolas Wolf. "Weber Revisited: The Protestant Ethic and the Spirit of Nationalism." Ann Arbor, MI: Inter-university Consortium for Political and Social Research [distributor], 2020-05-26. https://doi.org/10.3886/ E119604V1.

Knabe, Ferdinande. Sprachliche Minderheiten und nationale Schule in Preußen zwischen 1871 und 1933: Eine bildungspolitische Analyse. Münster: Waxmann, 2000.

Königlich Statistisches Bureau. Preussische Statistik Band 30. Verlag des Königlichen Statistischen Bureaus, 1875. 
Lamberti, Marjorie. State, Society, and the Elementary School in Imperial Germany. Oxford: Oxford University Press, 1989.

Lehmann, Hartmut, and Guenther Roth (eds.). Weber's Protestant Ethic: Origins, Evidence, Contexts. Cambridge: Cambridge University Press, 1995.

Lehmann-Hasemeyer, Sibylle, and Fabian Wahl. "Savings Banks and the Industrial Revolution in Prussia Supporting Regional Development with Public Financial Institutions." CEPR Discussion Paper No. 12500, London, UK, 2017.

Lusardi, Annamaria, and Olivia S. Mitchell. "Financial Literacy around the World: An Overview." NBER Working Paper Series No. 17107, Cambridge, MA, 2011.

MacKinnon, M. H. "The Longevity of the Thesis." In Weber's Protestant Ethic: Origins, Evidence, Context, edited by Hartmut Lehmann and Guenther Roth, 211-43. Cambridge: Cambridge University Press, 1995.

Margo, Robert A. "The Integration of Economic History into Economics." NBER Working Paper Series No. 23538, Cambridge, MA, 2017.

Martin, Rudolf. Jahrbuch des Vermögens und Einkommens der Millionäre in Preußen. Berlin: Verlag W. Herlet, 1912.

Molik, W. "Inteligencja polska w dziewietnastowiecznym Poznaniu. Liczebnosc i strukture zawodowa." In Inteligencja Poznanska. Historia I wspomnienia, edited by J. Wiesiolowski, 9-33. Poznan: Kronika Miasta Poznania, 1998.

Mommsen, Wolfgang J. Max Weber und die deutsche Politik 1890-1920. Tübingen: Mohr Siebeck, 2004.

Nolan, Patrick, and Gerhard Lenski. Human Societies: An Introduction to Macrosociology. Oxford: Oxford University Press, 2014.

Offenbacher, M. Konfession und soziale Schichtung. Eine Studie über die wirtschaftliche Lage der Katholiken und Protestanten in Baden. Tübingen: J.C.B. Mohr (Paul Siebeck), 1901.

Politische Abteilung des königlichen Polizeipräsidiums in Posen. Rechenschaftsberichte für das Jahr 1907 (Sonderausgabe des Gesamtüberblicks über die polnische Tagesliteratur). Posen: Merzbach'sche Buchdruckerei, 1909.

Rubin, Jared. "Printing and Protestants: An Empirical Test of the Role of Printing in the Reformation." Review of Economics and Statistics 96, no. 2 (2014): 27086.

Schilling, Heinz. Höfe und Allianzen. Deutschland 1648-1763. Berlin: Siedler, 1994.

Schindling, Anton, and Walter Ziegler. Die Territorien des Reichs im Zeitalter der Reformation und Konfessionalisierung: Land und Konfession 1500-1650: Band 1 Der Südosten. Münster: Aschendorff, 1989.

- Die Territorien des Reichs im Zeitalter der Reformation und Konfessionalisierung: Land und Konfession 1500-1650: Band 4 Mittleres Deutschland. Münster: Aschendorff, 1992.

- Die Territorien des Reichs im Zeitalter der Reformation und Konfessionalisierung: Land und Konfession 1500-1650: Band 2 Der Nordosten. Münster: Aschendorff, 1993a.

- Die Territorien des Reichs im Zeitalter der Reformation und Konfessionalisierung: Land und Konfession 1500-1650: Band 5 Der Südwesten. Münster: Aschendorff, 1993b.

- Die Territorien des Reichs im Zeitalter der Reformation und Konfessionalisierung: Land und Konfession 1500-1650: Band 3 Der Nordwesten. Münster: Aschendorff, 1995. 


\section{The Protestant Ethic and the Spirit of Nationalism}

- Die Territorien des Reichs im Zeitalter der Reformation und Konfessionalisierung: Land und Konfession 1500-1650: Band 6 Nachträge. Münster: Aschendorff, 1996.

Schönpflug, Daniel. Die Heiraten der Hohenzollern. Verwandtschaft, Politik und Ritual in Europa 1640-1918. Göttingen: Vandenhoeck und Ruprecht, 2013.

Schutte, Christoph. Die Königliche Akademie in Posen (1903-1919). Marburg: Herder Institut, 2008.

Scott, Alan. "Book Review: Jack Barbalet, Weber, Passion and Profits." Canadian Journal of Sociology 34, no. 3 (2009): 903-5.

Spenkuch, Jörg L. "Religion and Work: Micro Evidence from Contemporary Germany." Journal of Economic Behavior \& Organization 135, no. 3 (2017): 193-214.

Spenkuch, Jörg L., and Philipp Tillmann. "Elite Influence? Religion and the Electoral Success of the Nazis." American Journal of Political Science 62, no. 1 (2018): $19-36$.

Suesse, Marvin, and Nikolaus Wolf. "Rural Transformation, Inequality, and the Origins of Microfinance." Journal of Development Economics 143 (2020): 102429.

Tabellini, Guido. "The Scope of Cooperation: Values and Incentives." Quarterly Journal of Economics 123, no. 3 (2008): 905-50.

Trende, Adolf. Geschichte der deutschen Sparkassen bis zum Anfang des 20. Jahrhunderts. Stuttgart: Deutscher Sparkassen-Verlag, 1957.

Troeltsch, E. Der Historismus und seine Probleme. Tübingen: Mohr, 1922.

Trzeciakowski, Lech. Kulturkampf w zaborze pruskim. Poznan: Wydawn, 1970.

Verband der Ärzte Deutschlands. Verzeichnis der Ärzte im Deutschen Reiche und deutscher Ärzte im Auslande. Leipzig: Verband der Ärzte Deutschlands, 1908.

von Knebel Doeberitz, Hugo. Das Sparkassenwesen in Preußen. Berlin: Mittler, 1907.

Weber, Max. "Der Nationalstaat und die Volkswirtschaftspolitik. Akademische Antrittsrede." In Max Weber Gesamtausgabe. Band 4. Landarbeiterfrage, Nationalstaat und Volkswirtschaftspolitik. Schriften und Reden 1892-1899, edited by W. Mommsen, 543-74. Tübingen: J.C.B. Mohr (Paul Siebeck), 1895.

—. "Die protestantische Ethik und der Geist des Kapitalismus." Archiv für Sozialwissenschaften und Sozialpolitik 20, no. 1 (1904): 1-54.

—. "Die protestantische Ethik und der Geist des Kapitalismus." Archiv für Sozialwissenschaften und Sozialpolitik 21, no. 1 (1905): 1-110.

- The Protestant Ethic and the Spirit of Capitalism. Translation: Talcott Parsons. London: George Allen \& Unwin Ltd, 1930.

Wehler, Hans-Ulrich. Deutsche Gesellschaftsgeschichte. Dritter Band 1849-1914. München: C.H. Beck, 2006.

Wolf, Nikolaus. "Was Germany Ever United? Evidence from Intra- and International Trade, 1885-1933." Journal of Economic History 69, no. 3 (2009): 846-81.

Zeumer, Karl (ed.). Quellensammlung zur Geschichte der Deutschen Reichsverfassung in Mittelalter und Neuzeit. 2, Von Maximilian I. bis 1806. Tübingen: J.C.B. Mohr (Paul Siebeck), 1913.

Zimmerman, Andrew. "Decolonizing Weber.” Postcolonial Studies 9, no. 1 (2006): 53-79. 